Danbolt, J., Siganos, A. and Tunyi, A. (2016) Abnormal returns from takeover prediction modelling: challenges and suggested investment strategies. Journal of Business Finance and Accounting, 43(1-2), pp. 66-97. (doi:10.1111/jbfa.12179)

There may be differences between this version and the published version. You are advised to consult the publisher's version if you wish to cite from it.

This is the peer-reviewed version of the following article: Danbolt, J., Siganos, A. and Tunyi, A. (2016) Abnormal returns from takeover prediction modelling: challenges and suggested investment strategies. Journal of Business Finance and Accounting, 43(1-2), pp. 66-97, which has been published in final form at 10.1111/jbfa.12179. This article may be used for non-commercial purposes in accordance with Wiley Terms and Conditions for Self-Archiving.

http://eprints.gla.ac.uk/116499/

Deposited on: 16 February 2016

Enlighten - Research publications by members of the University of Glasgow http://eprints.gla.ac.uk 


\title{
Abnormal Returns from Takeover Prediction Modelling: Challenges and Suggested Investment Strategies
}

\author{
Jo Danbolt* \\ Professor of Finance \\ University of Edinburgh
}

Antonios Siganos

Senior Lecturer in Finance

University of Glasgow

\author{
Abongeh Tunyi \\ Lecturer in Accounting \& Finance \\ Liverpool Hope University
}

*Corresponding author

\begin{abstract}
Acknowledgements: We are grateful to an anonymous referee, Ronan Powell (associate editor), Bill Rees, José Yagüe and participants at the BAFA (Manchester) 2015 conference, the BAFA Scottish (Edinburgh) 2015 conference and the XI Workshop on Empirical Research in Financial Accounting (Cordoba) 2015 for helpful comments on previous versions of this paper. Jo Danbolt holds the Baillie Gifford Chair in Financial Markets, and his research is partially funded by a Baillie Gifford endowment held by the University of Edinburgh Business School. Baillie Gifford has no role in or influence over the research conducted.
\end{abstract}




\title{
Abnormal Returns from Takeover Prediction Modelling: Challenges and Suggested Investment Strategies
}

\begin{abstract}
While takeover targets earn significant abnormal returns, studies tend to find no abnormal returns from investing in predicted takeover targets. In this study, we show that the difficulty of correctly identifying targets ex ante does not fully explain the below-expected returns to target portfolios. Target prediction models' inability to optimally time impending takeovers, by taking account of pre-bid target underperformance and the anticipation of potential targets by other market participants, diminishes but does not eliminate the potential profitability of investing in predicted targets. Importantly, we find that target portfolios are predisposed to underperform, as targets and distressed firms share common firm characteristics, resulting in the misclassification of a disproportionately high number of distressed firms as potential targets. We show that this problem can be mitigated, and significant risk-adjusted returns can be earned, by screening firms in target portfolios for size, leverage and liquidity.
\end{abstract}

JEL Classification: G11, G12, G14, G34

Keywords: Takeover prediction, abnormal returns, portfolio strategies, investment timing, firm size, rumours 


\section{Introduction}

A large number of studies show that takeover targets experience significant stock price increases around merger announcements. Jensen and Ruback (1983), one of the first systematic reviews of the mergers \& acquisitions (M\&A) literature, reports weighted average abnormal returns of 29.1 percent for US targets in the month or two surrounding an offer. A comparative study by Franks and Harris (1989) based on UK data reports abnormal returns of a similar magnitude. More recent studies employing US, UK and EU samples (e.g., Georgen and Renneboog, 2004; Danbolt, 2004; Gregory and O’Donohoe, 2014) show comparable abnormal returns to targets, ranging from 19.5 to 31 percent in the days and months surrounding a bid.

Unsurprisingly, a number of studies (e.g., Palepu, 1986; Powell, 2001; Brar et al., 2009) explore whether a successful investment strategy can be developed by predicting potential targets. However, these studies report limited success despite finding that prediction models are fairly successful in identifying future targets. Powell (2001), for example, finds that the market- and size-adjusted returns to his UK target portfolio between $1^{\text {st }}$ January 1996 and $31^{\text {st }}$ December 1996 were -11.0 and -4.0 percent, respectively. Mirroring the conclusions of earlier studies, such as Palepu (1986) and Barnes (1999), Powell (2001, p. 1008) contends that 'developing statistical models to predict takeover targets is unlikely to result in a profitable investment strategy’. However, a small number of recent studies have reported that the generation of abnormal stock returns from takeover prediction is feasible. Using a small sample of Australian listed firms, Rodrigues and Stevenson (2013), for example, find that their model performs in line with the market in 2009, but outperforms the market in 2010 and 2011 when simple market-adjusted returns are considered. Their results are, however, only adjusted for risk using a simple market-adjusted returns model. To our knowledge, the most optimistic results have been reported by Brar et al. (2009). Their study, based on an EU 
sample, shows that a 'takeover timing portfolio' generates a modest alpha of 0.58 percent per month between 1995 and 2003 (Brar et al., 2009, p. 448). As discussed below, one potential reason for the gains reported by Brar et al. (2009) is the size restriction they impose by focusing on deals involving targets with market capitalisation in excess of $\$ 100$ million.

Our paper is motivated by the finding that target prediction models have some predictive ability (at least, better than random classification); targets gain substantially from takeover activity, yet portfolios of predicted targets fail to outperform the market. We contribute to the literature in two broad areas. First, we explore the underlying factors that influence the stock returns of predicted target portfolios. Amongst these are issues of poor timing, prediction errors and the tendency for distressed firms to be identified as potential targets. Second, we investigate potential strategies for mitigating the effects of these factors. In particular, we show that by screening firms in target portfolios for size, leverage and liquidity, the effect of distressed firms can be reduced and significant abnormal returns can be generated from the investment strategy.

With respect to the factors influencing target portfolio stock returns, we highlight three potential reasons why portfolios generated from takeover prediction models fail to generate abnormal returns, and we investigate these by developing nine testable hypotheses. First, we examine the predictive ability of current prediction models and whether the prediction models' inability to correctly predict a substantial number of future targets explains the low returns to target portfolios (as suggested by Palepu, 1986; Barnes, 1999; Powell, 2001, 2004; Cahan et al., 2011). Prediction models underperform if the predicted targets (or firms with high takeover likelihood) do not eventually receive takeover bids. Prior studies suggest that these firms (described as type II errors) are strategically better off if acquired. Given that takeover targets generally underperform prior to takeovers (Palepu, 1986; Powell, 2001), the expectation is that such firms are likely to continue to underperform 
unless they become a takeover target. The presence of type II errors in the portfolio of predicted targets will, perhaps, explain a substantial portion of the low returns to these portfolios. We hypothesise that (i) type II errors underperform the typical non-target (hypothesis 1); and (ii) target portfolios stripped of type II errors earn significant abnormal returns (hypothesis 2). If the presence of type II errors explains the low returns to target portfolios, then the literature will benefit from the development of better prediction models.

Second, we explore the challenge of optimal timing in target prediction, and whether poor timing in prediction potentially explains the low returns to target portfolios. The challenge arises from the finding that targets tend to perform poorly over several months prior to the bid announcement, but start to generate significant returns as the announcement date draws closer (we confirm this later in our study). This suggests that holding targets later rather than sooner might be of some benefit. Nonetheless, other market participants are likely to anticipate potential takeover bids as the bid date draws near, thus reducing any abnormal returns to be generated from the strategy. To our knowledge, our study is the first to consider the significance of timing when predicting takeover targets.

To elaborate, optimal timing is hampered, as target prediction models employ firm fundamental values; therefore, annual portfolio rebalancing is used in takeover prediction modelling (see, for example, Palepu, 1986; Barnes, 1999; Powell, 2001; Powell and Yawson, 2007; Cremers et al., 2009; Brar et al., 2009). However, the predictions may be may be made so early that the stock returns of targets experience a significant decrease before the pre-bid upward movement in stock price commences. We might, therefore, find very low returns to correctly predicted targets. Further, takeover prediction models exist in the public domain, and other market participants are likely to employ similar strategies. We should, therefore, expect to find evidence of market anticipation of predicted targets. We hypothesise that the returns to actual targets in target portfolios are low, as several potential targets are included in 
the portfolio either too early or too late (hypothesis 3). To directly test the effect of anticipation by other market participants using similar models, we also hypothesise that takeover targets which are correctly predicted by our model are less of a surprise to the market, and, hence, earn significantly lower abnormal returns than targets which we are unable to predict (hypothesis 4).

Third, we explore whether target characteristics that match those of firms that are predisposed to experience financial distress explain the difficulty of generating abnormal stock returns from target prediction models. Prior research (e.g., Pastena and Ruland, 1986; Clark and Ofek, 2004; Powell and Yawson, 2007) suggests that targets and bankrupt firms share similar characteristics, and, therefore, mergers and bankruptcy are alternative forms of reorganisation facing firms in distress. Targets and distressed (bankrupt) firms tend to be small firms with poor stock performance (Powell and Yawson, 2007). Takeover prediction models are therefore likely to select as potential targets firms that are simultaneously classified as candidates for bankruptcy. Prior takeover prediction studies (e.g., Palepu, 1986; Powell, 2001; Brar et al., 2009) ignore the impact of this tendency and hence overstate portfolio returns by not recognising the significant loss occurring when predicted targets exit the portfolio through bankruptcy.

To our knowledge, our study is the first to consider the impact of bankruptcies on the profitability of investing in predicted takeover targets and to propose a strategy for mitigating its effect. We can directly address the issue of investing in firms that eventually go bankrupt by explicitly trying to identify these firms ex ante and excluding them from our target portfolio. We adopt an existing bankruptcy prediction model - the Taffler Z score model (Taffler, 1983) - to help us identify and eliminate potential candidates for bankruptcy prior to portfolio formation. The empirical evidence suggests bankruptcy prediction models identify firms in distress with a considerable level of error (Agarwal and Taffler, 2008) and hence, 
should be used with some caution. Still, we hypothesise that stock returns are stronger when firms with low Taffler Z scores are excluded from target portfolios (hypothesis 5).

Our second solution to the distress problem builds on research findings that merging firms are larger and less leveraged than their counterparts which reorganise through bankruptcies (Pastena and Ruland, 1986). By using market capitalisation as a noisy (yet efficient) proxy to identify candidates for bankruptcy, we can mitigate its effect on our portfolio returns by reducing our net investment in firms that might potentially go bankrupt. We hypothesise that stock returns are stronger when excluding small capitalisation firms that are more likely to become insolvent (hypothesis 6). We can explore this by screening our portfolios for small firms.

Nonetheless, prior research also suggests that the largest firms tend to be shielded from acquisition (Palepu, 1986). This implies that if the size cut-off in our screen is set so as to invest only in very large companies, we might avoid investing in most firms that eventually go bankrupt, but we will also be unlikely to invest in many firms that eventually receive takeover bids. We test this empirically by hypothesising that stock returns are weaker when investing only in large capitalisation firms that are less likely to become targets (hypothesis 7). Jointly, hypotheses 5 and 6 suggest that there is a benefit (avoid firms that go bankrupt) and a drawback (less likely to invest in takeover targets) to investing in larger firms only. This would suggest that the traditional value-weighting strategy for portfolio formation might not address this problem, as it gives less weight to small firms, which may be more likely to suffer financial distress, but more weight to firms which are unlikely to be actual targets (hypothesis 8).

Alternatively, we explore whether other bankruptcy indicators, including measures of the degree of firm leverage and firm liquidity, can be more effective in screening target portfolios for firms in financial distress. Prior research (e.g., Taffler, 1983; Pastena and 
Ruland, 1986; Agarwal and Taffler, 2008; Powell and Yawson, 2007) suggests that bankrupt firms are characterised by low liquidity and high leverage. Hence, we hypothesise that stock returns are stronger when firms with high leverage and/or low liquidity are excluded from target portfolios (hypothesis 9). Ultimately, hypotheses 6 and 9 can be combined to explore whether target portfolio stock returns can be improved by screening for size, leverage and liquidity.

We employ UK data between 1988 and 2011 to test our developed hypotheses. We find that a conventional target prediction model generates positive but marginal risk-adjusted returns of up to 0.4 percent per month (using the Capital Asset Pricing Model; CAPM), which is generally insignificant. This result is partly attributed to the model's misclassification of several non-targets as targets (type II errors), as we find that target portfolios without type II errors generate substantial abnormal stock returns of up to 1.5 percent per month (CAPM), significant at the one percent level. While substantial, the annual buy-and-hold abnormal returns (BHAR) to these target-only portfolios are still well below the 19.5-31 percent BHAR or cumulative abnormal returns (CAR) to M\&A targets reported in prior studies (Georgen and Renneboog, 2004; Danbolt, 2004; Gregory and O’Donohoe, 2014). This finding accentuates the significance of accurate timing in the prediction of potential targets. If the model selects targets too early, investors would achieve significant losses prior to the target price run-ups, as targets tend to underperform in the months leading up to a bid. If, on the contrary, the model predicts targets too late, the potential gains to investors are significantly reduced. We argue that accurate timing to minimise the effect of pre-bid underperformance while outsmarting other market participants remains a major challenge to the strategy. We explore whether this timing problem could be mitigated by the use of qualitative information, such as merger rumours. While our documented rumours are 
useful in improving timing (as several bids are preceded by rumours), the adoption of a rumour screening strategy does not allow us to generate significant abnormal returns.

Our study further highlights the tendency for target prediction models to identify a disproportionately high number of bankrupt firms as potential targets, leading to a significant reduction in stock returns. We explore different strategies for identifying and/or reducing the number of bankrupt firms within our target portfolios, including the use of Taffler Z scores and the use of size, liquidity and leverage screens. We find that the screening strategy substantially improves returns to target portfolios. For example, our target portfolio riskadjusted returns (CAPM) increases from 0.4 percent per month (insignificant) to 0.7 percent (significant at the five percent level) when we exclude all predicted targets with high leverage (in the top two quintiles). A combination strategy which screens target portfolio by size, liquidity and leverage (i.e., eliminates predicted targets in the bottom two size quintiles or the bottom two liquidity quintiles or the top two leverage quintiles) generates significant riskadjusted returns (CAPM) of 0.9 percent per month.

The rest of our paper is organised as follows. Section 2 discusses the data and methodology. Section 3 presents the empirical results, and Section 4 concludes.

\section{Data and methodology}

We start by identifying a sample of all firms that are or have been listed on the main market of the London Stock Exchange between July 1988 and June 2011. ${ }^{1}$ Financial firms (SIC code 6000-6999) are excluded from the analysis as they are known to follow unique reporting standards, which makes the interpretation of their financial ratios different from those of other firms (e.g., Renneboog and Trojanowski, 2007). The final sample consists of 
2,970 firms. We obtain firm accounting data and stock returns from DataStream, and merger characteristics from Thomson OneBanker. The two databases are matched using firm DataStream codes.

We focus on takeover bids, even if they eventually fail. Consistent with prior studies (e.g., Cornett et al., 2011; Ambrose and Megginson, 1992), we restrict our sample of targets to those that receive bids which, if completed, would result in the bidder gaining control (greater than 50 percent shareholding) of the target. We obtain data for 2,799 M\&A announcements involving publicly listed UK targets between $1^{\text {st }}$ June 1989 and $30^{\text {th }}$ June 2011. This list excludes bids for minority interest, rumours or intentions, and announcements involving targets in the financial industry. We further exclude subsequent bids for the same target firm at different points within the same year. This generates a sample of 1,635 unique targets. In untabulated results, we find that out of an average of 1,471 listed firms per year, 74 firms (5.05 percent of listed firms) receive a bid in any one year on average. This level of takeover activity is similar to the 5.00 percent (between 1986 and 1995) reported by Powell (2004), and varies from one year to another, with a high of 9.80 percent in 1997 and a low of 2.55 percent in 1993.

We use time-varying firm, industry and market characteristics to predict potential takeover targets. In line with Palepu (1986), we first adopt the following five hypotheses for the prediction of takeover targets: inefficient management, firm undervaluation (misevaluation), industry disturbance, growth-resource mismatch and firm size hypotheses. Consistent with Powell (1997) and Ambrose and Megginson (1992), we also incorporate two additional hypotheses for takeover prediction: the free cash flow and the tangible assets hypotheses. Following Pakes and Ericson (1998) and Agarwal and Gort (2002), we add firm age as a determinant of firm takeover likelihood. These eight hypotheses, variants of which have been widely used across the literature (see, for example, Ambrose and Megginson, 
1992; Barnes 1998, 1999, 2000; Powell, 1997, 2001, 2004; Espahbodi and Espahbodi, 2003), are used to develop a 'conventional' model. Further details on these hypotheses are provided below.

The inefficient management hypothesis stipulates that takeovers play a disciplinary role through which an underperforming management team is replaced through a takeover. We use two proxies, the return on capital employed (ROCE) and average monthly excess returns (AER), to capture management performance. Following Palepu (1986) and Powell and Yawson (2007), AER is computed as a firm's average monthly excess return over the market (FTSE All Share) return for the year to June.

The misvaluation hypothesis suggests that the stock market's inefficiency in the valuation of firms has important effects on takeover activity. The effects arise from the bidders' deliberate efforts to 'profit by buying undervalued targets for cash at a price below fundamental value, or by paying equity for targets that, even if overvalued, are less overvalued than the bidder' (Dong et al., 2006, p. 726). Following Shleifer and Vishny (2003) and Bi and Gregory (2011), in absolute terms (i.e., with no knowledge of the characteristics of the bidder), we would expect targets of cash acquisitions to be undervalued, and targets in stock-financed acquisitions to have higher valuation on average, and possibly even be overvalued. ${ }^{2}$ We use Tobin's Q (market value to replacement cost of assets) to proxy for the level of target misvaluation. Consistent with Hasbrouck (1985) and Dong et al. (2006), Tobin's Q is estimated as the sum of the book value of debt (i.e., the difference between the book value of assets and the book value of equity) and the market value of equity, scaled by the book value of assets.

The industry disturbance hypothesis suggests that a firm's takeover likelihood will increase with the announcement of a merger bid in that industry. Consistent with Palepu

\footnotetext{
${ }^{2}$ We confirm this in additional analyses later in our study.
} 
(1986), Walter (1994) and Lin et al. (2014), we use the industry disturbance dummy variable (IDDummy) to capture industry disturbances. IDDummy takes a value of one if any merger is completed within a firm's industry in the year prior to the bid in question, and a value of zero otherwise. We define industries using the UK four-digit SIC code classification system.

The growth-resource mismatch hypothesis suggests that low-growth but resource-rich firms, as well as high-growth but resource-poor firms, are more likely to become takeover targets. Consistent with prior studies (e.g., Palepu, 1986), we use four variables, including sales growth (SGrowth), firm liquidity (cash to total assets ratio), leverage (debt to equity ratio) and a growth-resource imbalance dummy variable (GRDummy), as proxies. An imbalance between growth opportunities and resources is said to occur when (1) a firm has high sales growth accompanied by low liquidity and high leverage, or when (2) a firm has low sales growth accompanied by high liquidity and low leverage. These variables are characterised as 'low' or 'high' by comparing them with the four-digit SIC code industryyear average. The GRDummy takes a value of one in these two cases ((1) and (2) above) and a value of zero in all other combinations of growth, liquidity and leverage.

The firm size hypothesis argues that takeover probability decreases with firm size, as the number of viable bidders for a target decreases as its size increases (Palepu, 1986; Powell, 2001; Gorton et al., 2009). Consistent with Powell (1997), Powell and Yawson (2007), Cornett et al. (2011) and De and Jindra (2012), firm size is proxied by the natural log of total assets.

The free cash flow hypothesis stipulates that takeover likelihood increases with a firm's level of free cash flow. In an active market for corporate control, management which hoards or misappropriates excess free cash flow is likely to face a challenge for corporate control (Manne, 1965; Jensen, 1986; Powell, 1997). Besides the opportunity to correct management inefficiency, the bidding firm is further attracted by the excess free cash flow in 
the target firm, as this free cash flow can be used to reduce the net cost of acquisition. Consistent with Powell and Yawson (2007), free cash flow (FCF) is defined as the ratio of net cash flow from operating activities less capital expenditures scaled by total assets.

The real property hypothesis predicts that firms with substantial tangible fixed assets (such as plant and machinery) in their total asset portfolio are more attractive targets to bidders (Ambrose and Megginson, 1992). Tangible fixed assets proxy for debt capacity and provide financial slack to enable a firm to raise debt capital in times of need (Myers and Majluf, 1984; Stulz and Johnson, 1985; Ambrose and Megginson, 1992). These assets can reduce a bidder's implicit takeover cost, as they can be divested to raise the funds needed to complete the transaction. Consistent with prior studies (e.g., Powell, 1997; Ambrose and Megginson, 1992), the ratio of property, plant and equipment to total assets is used as a measure for tangible assets.

The firm age hypothesis suggests that takeover probability decreases with firm age (Brar et al., 2009; Bhattacharjee et al., 2009; Loderer and Waelchli, 2015). Firm survival (age) is frequently attributed to a firm's endowments and its tendency to learn-by-doing over time (Pakes and Ericson, 1998; Agarwal and Gort, 2002; Bhattacharjee et al., 2009). Agarwal and Gort (2002) contend that, over time, a firm gains knowledge about itself and its industry, which allows it to achieve cost reductions and product improvements, and develop new market techniques. Firm endowments are generally low when firms are born, but increase over time as firms invest in research and development (Agarwal and Gort, 2002). Hence, the probability of firm survival (takeover) within an industry increases (decreases) as firms grow older. Firm age is proxied by the number of years since incorporation.

A summary of our hypotheses and the component variables is shown in Appendix 1. We eliminate outliers from our dataset by winsorising ROCE, AER, Tobin's Q, sales growth, liquidity, leverage, free cash flow and tangible assets at the $1^{\text {st }}$ and $99^{\text {th }}$ percentiles. No 
adjustments are made to the industry disturbance or growth-resource mismatch dummies, firm size and firm age. ${ }^{3}$ Note that to mitigate any look-ahead bias, we impose a time lag in our model which maintains that a firm's takeover probability in the next period $(t+1)$ is a function of its publicly available financial information in the most recent period $(t)$. We follow the June approach (Soares and Stark, 2009) by developing the model on June $30^{\text {th }}$ of each year (using accounting data up to the financial year-end of $31^{\text {st }}$ December of the previous year), to predict and invest in targets from July $1^{\text {st }}$. The computation of ratios which utilise market data matches, for example, June $30^{\text {th }}$ (2010) market data with accounting statement data for the previous financial year-end (2009). Our final dataset is made up of 32,363 firm-year observations over a 22-year period (1988-2009).

We model takeover likelihood in the spirit of Palepu (1986), Powell (2001), Cremers et al. (2009) and Lin et al. (2014). Our base regression model is the logit model given as follows:

$$
P_{i t}=\frac{1}{1+e^{-Z_{i t-1}}}
$$

where $P_{i t}$ is the probability that firm $i$ will be acquired in the current period $(t)$ and $Z_{i t-1}$ is a vector of firm i's characteristics in the previous period ( $t-1)$, given as follows:

$$
Z_{i t-1}=\beta_{0}+\beta_{1} X_{1 i t-1}+\beta_{2} X_{2 i t-1}+\cdots+\beta_{k} X_{k i t-1}+\varepsilon_{i t-1}
$$

$\beta_{0}$ is the intercept term and $\beta_{j}(j=1, \ldots, k)$ represents the coefficients associated with the corresponding independent variables $X_{j}(j=1, \ldots, k)$ for each firm. The dependent variable $P_{i t}$ in our model takes the value of one if a firm (i) is the subject of a takeover in a period $(t)$, and a value of zero otherwise.

3 In untabulated results, we follow alternative outlier treatments, and results remain qualitatively similar. 


\section{Empirical results}

\subsection{Descriptive statistics and model development}

We start by developing our prediction model using our panel dataset. Table 1 reports the differences in the characteristics of targets and non-targets within a univariate framework. We find that targets have higher operating performance (ROCE), but experience lower excess stock returns (AER) than non-targets in the year prior to a merger announcement. These results are consistent with Agarwal and Jaffe's (2003) finding that US targets do not underperform in terms of operating performance, but do not support their argument that the targets do not also underperform in terms of stock market performance. The targets in our sample have a lower Tobin’s Q, lower liquidity and higher leverage in relation to counterpart non-targets. We further find that targets have higher levels of tangible assets and free cash flow, and are younger compared to non-targets. The higher free cash flow of targets is, perhaps, due to their higher levels of profitability. The results on firm size (i.e., targets are larger than non-targets) are particularly puzzling, as some studies (including Barnes, 1999 and Powell, 2001) hypothesise a negative relation between firm size and takeover likelihood. In untabulated results, we find that the purported negative relation is only robust when we exclude small firms from our sample. The results are consistent with Powell and Yawson (2007), who find that UK targets have significantly lower liquidity, higher leverage, lower stock returns and larger size compared to non-targets. Our findings are robust to different outlier management procedures and consistent with the management inefficiency, misevaluation (undervaluation argument), tangible property, free cash flow and firm age hypotheses.

[Insert Table 1 around here] 
We use a multivariate framework to explore the relation between the above firm characteristics and firm takeover likelihood by estimating binomial logistic regressions. We first estimate Pearson and Spearman correlations and the variance inflation factors. These results are available upon request. We find that the level of correlation among our variables is modest and unlikely to lead to multicollinearity concerns. Table 2 reports the parameter coefficients of the logistic regressions, where the dependent variable is the takeover likelihood. We present results for logit estimations with clustering of standard errors by firm and year.

[Insert Table 2 around here]

We find empirical support for the inefficient management (average excess return), undervaluation (Tobin’s Q), tangible assets, free cash flow and firm age hypotheses, but no support for the growth resource mismatch, industry disturbance or firm size hypotheses. The coefficients of the growth-resource mismatch and industry disturbance dummies are not significant, but we find that takeover likelihood declines with firm liquidity. Our main results are consistent with those reported in prior UK studies, such as Powell and Yawson (2007), who for UK firms between 1992 and 2001 find that takeover likelihood decreases with average abnormal returns and increases with firm size.

\subsection{Model predictive ability}

As in prior studies (e.g., Palepu, 1986; Bartley and Boardman, 1990; Barnes, 1999, 2000; Espahbodi and Espahbodi, 2003; Powell, 2001; Pasiouras et al., 2007), we employ an out-of-sample period to also evaluate the predictive ability of the model. Firms are ranked by their predicted takeover probability, and the 20 percent of firms with the highest takeover probability (Quintile 5 or Q5) is selected as our target portfolio. ${ }^{4}$ Following Cremers et al. 
(2009), we adopt a recursive model evaluation technique, where the model is recurrently redeveloped using new data and is tested over several holdout periods between 1995 and 2009. The target concentration ratio, a measure of model performance, is the proportion of True Positives within the target portfolios.

As shown in Figure 1, we find that the target concentration ratio achieved by the model (in the top quintile) varies throughout the sample period and is, on average, equal to 8.52 percent. The model correctly predicts a total of 302 targets, out of 3,545 predictions over the fifteen-year period. Note that the model outperforms prior UK models ${ }^{5}$ as well as a random selection approach to target prediction. Recall that in any one year, on average 5.05 percent of our population were targets, and therefore the model's predictive ability outperforms a random selection of potential targets. The average difference in target concentration ratio across the fifteen-year holdout period is significant at the one percent level (p-value of 0.000).

[Insert Figure 1 around here]

\subsection{Abnormal returns earned by the target prediction model}

Next, we estimate the abnormal stock returns generated by the prediction model using monthly stock returns, as advocated by Gilbert et al. (2014). Given the general scepticism about the UK's version of the Carhart (1997) model (see Gregory et al., 2013), we adjust our target portfolio returns for risk using the capital asset pricing model (CAPM) of Sharpe (1964) and the Fama and French (1992) three-factor model (FF3F), and by also using control or benchmark portfolios. ${ }^{6}$ The data for the monthly risk-free rate $(R F)$, the monthly market

\footnotetext{
5 We compare our results directly with those of prior UK studies, mainly Powell $(2001,2004)$. Sample restrictions do not allow for a direct comparison with Barnes $(1998,1999,2000)$ and Powell $(1997)$. We adopt the same time period and portfolio selection approach used by Powell (2001, 2004) for developing and testing our model. Powell (2001) and Powell (2004) achieve an out-of-sample target concentration of 2.44 percent and 4.72 percent in 1996, respectively. Our model achieves a higher target concentration of 12.5 percent in the same period.

${ }^{6}$ Results for Carhart model estimations are not materially different. These results are available on request.
} 
return $(R M)$ and the risk factors, including size $(S M B)$ and book-to-market $(H M L)$, are collected from Gregory et al. (2013). We compute buy-and-hold abnormal returns (BHAR) using market, size, market-to-book and combined size and book-to-market benchmark portfolios following the procedure in Barber and Lyon (1997). In each year, we calculate the buy-and-hold return (BHR) on each security in our sample using monthly returns in the year to June. All firms in each year constitute our market benchmark portfolio. To generate the size (or the book-to-market) benchmark portfolios, we first rank firms by their market value (or book-to-market value) on the $1^{\text {st }}$ of July of each year. Next, we group them into ten deciles, with decile 10 constituting the ten percent of firms with the largest market (or bookto-market) value in each year. Finally, we combine our ten size and ten book-to-market deciles to create 100 portfolios (combinations) ranked by both size and book-to-market values. As in Barber and Lyon (1997), a firm's BHAR is the difference between its BHR and the BHR of its corresponding size, book-to-market and combined size and book-to-market benchmark portfolio. The BHAR of the predicted target portfolio is obtained by averaging the BHARs of its constituent firms in each period. Following Lyon et al. (1999), we compute bootstrapped skewness-adjusted t-statistics and p-values for portfolios’ BHARs by drawing 1,000 bootstrapped resamples, each of a size equal to a quarter of our portfolio size (i.e., $\mathrm{n} / 4$ ). Table 3 presents results for equal-weighted portfolio abnormal returns (CAPM and FF3F regression alphas and BHARs).

[Insert Table 3 around here]

As in Model 1 of Table 3, we find that over the fifteen-year out-of-sample period, the prediction model generates CAPM risk-adjusted returns of 0.4 percent per month, which are not significant at the ten percent level (p-value of 0.191). The result obtained using the FF3F model is slightly lower ( 0.3 percent per month) but also significant at the ten percent level (pvalue of 0.099). Results obtained using the BHAR benchmarks are positive but, with the 
exception of the market and book-to-market benchmarks, not significant at the ten percent level. ${ }^{7}$ Overall, the results suggest that the risk-adjusted returns to the standard strategy of investing in predicted target portfolios are marginal (if any). The model's risk-adjusted return for the period $1^{\text {st }}$ July 1996 to $30^{\text {th }}$ June 2011 is, however, higher than the -4 percent per year (January to December) reported by Powell (2001) for predicted UK targets in 1996. It is, nonetheless, lower than the 0.6 percent per month reported by Brar et al. (2009) for predicted EU targets between January 1995 and December 2003. Overall, the results suggest that, despite our ability to correctly predict some targets, generating risk-adjusted returns from the strategy is challenging. In the remainder of the study, we explore why generating abnormal returns from predicted target portfolios is a difficult pursuit, and we recommend implementable strategies for improving target portfolio returns.

\subsection{Portfolio timing and target portfolio returns}

\subsubsection{Prediction errors partly explain portfolio underperformance}

We first explore whether prediction errors are responsible for the low returns to our target portfolio. If, in every year, we could accurately predict and invest in all the targets in the full sample, we would have generated CAPM-adjusted returns or a BHAR of about 1.20 percent per month (p-value $<0.000$ ) over the holding period (Table 3, Model 2). Indeed, we fail to include 76.69 percent of actual targets in our portfolio. In addition, the model predicts that some of the firms in the sample will receive a bid during a particular year, but in 91.48 percent of instances (on average), no bid occurs (i.e., type II errors). However, we find that some of the type II errors eventually receive a takeover bid in a subsequent period. ${ }^{8}$ This suggests that portfolios might underperform because of the presence of type II errors and/or

\footnotetext{
7 In untabulated results, we estimate abnormal returns for different portfolio formation strategies, including deciles and optimal cut-off probabilities (see Powell, 2001). Our results remain qualitatively similar.

8 Some examples include National Express, UK Coal and JJB Sport. UK Coal, for example, appears in our target portfolio in 1997, 1998, 1999, 2002, 2007 and 2008 but only receives a bid in 2008.
} 
because of the time gap between the month/year of portfolio formation and the time of the actual bid. We first explore whether the type II errors within our portfolios exceptionally underperform or contribute to the poor returns to these portfolios. In empirical terms, we evaluate whether portfolios that fail to correctly predict any target significantly underperform. Conversely, as per hypothesis 2, we also investigate whether predicted target portfolios without type II errors generate positive abnormal stock returns.

As shown in Model 4 of Table 3, we find that the portfolio of type II errors does not generate positive abnormal returns. When we exclude actual targets from our portfolios, the CAPM alphas to these portfolios decline from 0.4 percent (in Model 1) to 0 percent per month (in Model 4). Similar results are obtained when other risk adjustment models, including FF3F and benchmark portfolios, are employed. Inconsistent with prior suggestions that type II errors are exceptional underperformers (Powell, 2001; Cahan et al., 2011), the portfolio of type II errors (Model 4) does not underperform the non-targets in the portfolio of predicted non-targets (Model 7). The non-targets in the portfolio of predicted non-targets generate a much lower CAPM-adjusted return of -0.6 percent per month (p-value of 0.050 ) and a FF3F-adjusted return of -0.8 percent per month (p-value $<0.000$ ). As predicted by hypothesis 2, when type II errors are excluded from our target portfolio (Model 3), the riskadjusted portfolio returns (CAPM) increase from 0.4 percent (p-value of 0.190 ) to 1.5 percent per month (p-value of 0.000 ). Overall, these results suggest that the targets which we correctly predict significantly contribute to improving the abnormal returns to our portfolios. Consistent with our first and second hypotheses, the evidence suggests that type II errors are principally responsible for the underperformance of our portfolios. In a later section, we revisit the issue of whether type II errors in the prediction model can be reduced. 


\subsubsection{Accurate timing is required to optimise returns to target portfolios}

Although the results in Model 3 of Table 3 show that the targets in our portfolio generate significant returns, the estimated annual BHAR of 14 percent (market benchmark) for this portfolio is substantially lower than the 19.5 to 31 percent abnormal returns to targets reported in prior studies (Jensen and Ruback, 1983; Franks and Harris, 1989; Georgen and Renneboog, 2004; Danbolt, 2004; Gregory and O’Donohoe, 2014). As per our hypothesis 3, we explore whether this difference can be attributed to the timing of bid announcements versus our portfolio inception dates. Panel A of Figure 2 shows the distribution of merger bids throughout a year, and, as expected, there is no clear pattern. Following the June approach, we use a portfolio inception date of July $1^{\text {st }}$ in each year, but only 8.7 percent of the bids in our sample are announced in July. There is thus a time gap between the month of the portfolio formation and the actual bid month in 91.3 percent of cases. Panel B of Figure 2 estimates the cumulative abnormal monthly returns to all targets in the sample, starting from 12 months before the bid (month -12) and ending 12 months after the bid (month 12). Consistent with the inefficient management hypothesis, we find that targets tend to perform poorly several months prior to receiving a bid. For example, the cumulative monthly stock returns from -11 months to -3 months are approximately -13 percent. Some of these negative returns are captured in the portfolios, given that researchers generally adopt a fixed portfolio holding period, such as the June approach. Consistent with our third hypothesis, this timing problem perhaps explains why a conventional annual rebalancing of portfolios generates lower than expected abnormal holding-period returns for actual targets.

[Insert Figure 2 around here] 


\subsubsection{Market anticipation reduces returns to predicted targets}

As the Efficient Market Hypothesis suggests, the prediction model would generate abnormal returns only if we can predict targets before other market participants. If our predictions are shared by the market, ${ }^{9}$ we should expect to earn lower returns from them even when they come to fruition. Figure 3 shows the abnormal stock returns over the period from 20 days (one trading month) before the merger announcement for firms with high takeover probability (predicted targets) that actually received a bid, and counterpart firms with low takeover probability (predicted non-targets) that received a bid. Predicted non-targets which receive a bid are likely to be a surprise to the market. Consistent with our fourth hypothesis, we find that firms with high takeover probability (Quintile 5, Figure 3) experience higher prebid target price run-ups and lower announcement returns (-1,1 days) in relation to their predicted non-target counterparts (Quintile 1, Figure 3). For example, the announcement effect for firms with low takeover probability is 22.50 percent versus 16.01 percent for high takeover probability counterparts. The difference is significant at the five percent level.

\section{[Insert Figure 3 around here]}

Consistent with our fourth hypothesis, our results suggest that some of the actual targets that the model succeeds in predicting do not earn high abnormal returns, as might be expected from the M\&A literature, perhaps due to parallel anticipation by other market participants. These results further emphasise the importance of timing, as the challenge is not only to correctly predict targets just a few months before takeover bids in order to avoid the pre-bid systematic target underperformance, but also to predict them ahead of other market participants.

9 The prediction model that we adopt in this study is in the public domain. Hence, we can reasonably expect that a similar model will be used by other market participants. 


\subsubsection{Can portfolio timing and returns be improved using rumour data?}

We now explore whether we can improve portfolio timing and reduce the effect of target pre-bid underperformance by using qualitative market signals, such as merger rumours. Given that rumours occur at specific dates, and prior studies (e.g., Jindra and Walking, 2004; Ahern and Sosyura, 2015; Chou et al., 2015) suggest that several takeovers are preceded by rumours, we explore whether information about the specific month in which a rumour occurs could be useful in improving the timing of portfolios. We collect data on merger rumours from Thomson OneBanker, where the rumoured targets are UK firms in our sample whose M\&A deal status is described as "intended, rumour or seeking buyer" ${ }^{10}$ For simplicity, we collectively describe these deals as "rumours" in subsequent discussions. We do not exclude cases in which the intent is eventually withdrawn, the rumour discontinued or the target withdraws its search for a buyer, as this could bias the analysis. However, the results do not change qualitatively when we exclude such cases.

Out of 453 takeover rumour-related news items over our portfolio holding period $\left(1^{\text {st }}\right.$ July 1996 to $30^{\text {th }}$ June 2011), 115 items correspond to firms in our target portfolio (an average of 7.67 rumours per year) and 70 correspond to firms in our non-target portfolio (an average of 4.67 rumours per year). The difference is statistically significant at the one percent level, suggesting an association between merger rumours and takeover likelihood.

We explore whether this set of rumours could be used to improve target portfolio returns. Focusing on rumours in our target portfolio, we plot (in Figure 4) the cumulative abnormal stock returns (1) around rumours, for all rumoured targets; (2) around rumours, for all rumoured targets that eventually receive a takeover bid; and (3) around merger bids, for all rumoured targets. That is, (2) and (3) plot the rumour returns and eventual bid announcement

10 An example of a rumour reported in Thomson OneBanker on 24th September 2009 is the following: "Microsoft Corp of the US was rumoured to be planning to launch a tender offer to acquire the entire share capital of Autonomy Corp PLC, a Cambridge-based developer of infrastructure software". 
returns, respectively, for bids which are preceded by merger rumours. Note that, as shown in the figure, most of the returns to rumoured targets (1) are earned on the day when the rumour emerges. Some of these rumoured targets eventually receive takeover bids (2). Importantly, the rumoured targets which eventually receive takeover bids (2) also earn significant abnormal returns when the merger bid is formally announced (3). This suggests that while we might not benefit from the initial rumour (as we are unlikely to be able to anticipate its emergence ex ante), we might earn returns once the rumour is followed by a formal takeover bid.

\section{[Insert Figure 4 around here]}

We use rumours to screen our target portfolio by investing in predicted targets only when they are associated with a rumour. To avoid look-ahead bias, we compute risk-adjusted returns to the rumoured target portfolio, starting from the month following the month in which the rumour emerges. As shown in Table 3 (Model 9), we find that the rumoured target portfolio generates risk-adjusted returns which are insignificant. ${ }^{11}$ Overall, these results suggest that, while there is a significant association between merger rumours and the emergence of takeover bids, such merger rumours (at least those in OneBanker) are unlikely to be useful when attempting to generate returns from the takeover prediction modelling. One reason for this is, perhaps, the limited number of rumours in our sample; there are several months/periods in which we do not invest in predicted targets as no rumours emerge. Overall, we do not find a viable solution to the timing problem.

\footnotetext{
${ }^{11}$ If we are able to capture the rumour returns as in Model 8, i.e., we invest in rumours before they emerge, the strategy yields a positive but statistically insignificant return. This is clearly not implementable.
} 


\subsection{Distressed firms and target portfolio returns}

\subsubsection{Distressed firms are misclassified as potential targets}

Evidence suggests that target and distressed (or bankrupt) firms share common firm characteristics (Powell and Yawson, 2007), which may explain the difficulty of generating abnormal returns from target portfolios. Consistent with this evidence, as shown in Figure 1, target prediction models are likely to classify a disproportionately high number of financially distressed (or bankrupt) firms as potential targets. In this study, we identify bankrupt UK firms using the LSPD's Master Index File. Firms with the following 'Type of Death' identifications are considered bankrupt: liquidation, delisted and all dealings terminated, receiver appointed, administrative receivership, and cancelled or suspended. In our analyses of portfolio returns, a -100 percent return in the firm delisting month has been assumed and was inserted to adjust for bankruptcy cost to investors.

Consistent with Powell and Yawson (2007), the results show that target portfolios have a disproportionately higher number of bankrupt firms. Indeed, 43.75 percent (and 13.54 percent) of the bankrupt firms in the sample are included in the quintile of firms with the highest (and lowest) takeover likelihood. This complements Pastena and Ruland's (1986) and Clark and Ofek’s (1994) argument that mergers and bankruptcies are alternative forms of reorganisation for firms in distress. To investigate the impact of bankrupt firms on abnormal stock returns, we exclude bankrupt firms from the target portfolios and compute the abnormal target returns to these portfolios. As shown in Table 4 (Model 1), we find that the returns to target portfolios generally improve significantly when bankrupt firms are excluded. The CAPM-adjusted portfolio returns become 0.6 percent per month, and are now significant at the five percent level. The monthly risk-adjusted returns generated using the FF3F model and benchmark portfolios are similarly about 0.2 percentage points higher. Nonetheless, for this 
to be implementable, one must be able to successfully identify and exclude bankrupt firms from target portfolios ex ante.

\subsubsection{The impact of distressed firms can be limited by imposing a ' $Z$ score', 'size', 'leverage’ or 'liquidity' screen}

We explore two main options for identifying bankrupt firms ex ante and mitigating their effects on portfolio returns. The first is to employ an existing bankruptcy prediction model to identify and exclude firms that have a high probability of going bankrupt, and the second is to use simple proxies for bankruptcy risk (firm market capitalisation, liquidity and/or leverage) to screen our portfolios for firms with high bankruptcy risk. Agarwal and Taffler (2008) suggest that the Taffler Z score model is still efficient in identifying firms in financial distress. We use model parameters from Taffler (1983) to estimate Taffler Z scores for all firms in our sample in every year between 1995 and 2009. In the next stage, we rank all firms in our sample by Z score and, from our target portfolio, we successively exclude all firms with Z scores in the bottom (Model 2) and bottom two Z score quintiles (Model 3). ${ }^{12}$ This allows us to invest only in predicted targets with corresponding high Z scores. The riskadjusted returns to target portfolios improve as we sequentially eliminate the first and then first and second quintiles of firms with low Z scores (Table 4, Models 2 and 3). The results do not improve further when more quintiles (i.e., third and fourth quintiles) are excluded.

In the second instance, we use firm market capitalisation as a proxy for financial distress, as research suggests that firms with higher market capitalisation are less likely to reorganise through bankruptcy (Pastena and Ruland, 1986; Clark and Ofek, 1994). We consider a simple size screening strategy, where we invest equally in all predicted targets

\footnotetext{
${ }^{12}$ In untabulated results, we also apply the zero Z score threshold suggested by Taffler (1983) to identify and exclude firms in financial distress from the target portfolio. This allows us to only eliminate 27.0 percent of bankrupt firms in the predicted target portfolio, and our target portfolio monthly FF3F-adjusted return falls from 0.3 percent (Table 3, Model 2) to 0.2 percent (and is no longer statistically significant).
} 
with a market value above a certain threshold. In untabulated results, when we impose a size threshold of $£ 50$ million (comparable to the $\$ 100$ million imposed by Brar et al. (2009)), we are able to exclude 99.3 percent of bankrupt firms in our target portfolio, but we also exclude 33 percent of actual targets in this portfolio. Consistent with hypothesis 6, this significant reduction in the number of bankrupt firms allows us to generate significant CAPM-adjusted returns of 0.6 percent per month (p-value of 0.071 ). Consistent with hypothesis 7 , the returns to target portfolios fall when substantially higher thresholds are imposed. For example, when a market value threshold of $£ 500$ million is imposed, the portfolio alpha (CAPM) is equal to 0.2 percent (p-value of 0.972 ). In untabulated results, we also find that other thresholds between $£ 50$ million and $£ 500$ million do not lead to substantial improvements in performance. Given that the $£ 50$ million threshold eliminates 99.3 percent of the bankrupt firms, this finding supports our contention that the improvement in portfolio returns when size screening is employed is largely explained by its exclusion of bankrupt firms.

To complement the use of size thresholds (for consistency), we rank all firms in our sample by market capitalisation, and successively exclude firms in the bottom size quintiles from our target portfolios. The returns to these target portfolios are reported in Table 4 (Models 5 and 6). Consistent with hypothesis 6, the results show that the elimination of predicted targets in the bottom two size quintiles leads to a slight improvement in portfolio returns (e.g., from CAPM-adjusted returns of 0.4 to 0.5 percent per month). ${ }^{13}$

Our eighth hypothesis is that traditional value-weighting strategies might not address the issue of bankruptcy of firms in our target portfolio. As in Table 4 (Model 4), consistent with this hypothesis, a value-weighting strategy does not yield significant positive portfolio returns. While such a strategy gives less weight to firms which are more likely to go bankrupt (i.e., small firms), it also gives more weight to large firms which are less likely to receive

${ }^{13}$ Additionally, the imposition of a higher size threshold (i.e., the elimination of Q1 and Q2 as opposed to just Q1) leads to significant FF3F, market BHAR and BTM BHAR, as shown in Model 6 of Table 4 . 
takeover bids. The net effect is that the strategy does not improve the returns from target prediction.

[Insert Table 4 around here]

Following our ninth hypothesis, we use firm leverage and liquidity to screen target portfolios for firms in financial distress by successively eliminating all firms in the top leverage and bottom liquidity quintiles before computing the portfolio risk-adjusted returns. Results from Models 7 and 8 of Table 4 show that portfolio returns continuously improve as we eliminate highly leveraged firms. When we eliminate the top two leverage quintiles, our portfolios report FF3F- and CAPM-adjusted returns of 0.7 percent per month, as well as BHARs of 0.4 percent per month, significant at the five percent level (Model 8). Similarly, the returns to our target portfolios improve as we eliminate stocks with low liquidity. For example, we achieve target portfolio CAPM-adjusted returns of 0.6 percent (p-value of 0.053) when we exclude all firms in the bottom two liquidity quintiles (Model 10). As before, the results do not further improve when the third and fourth quintiles are also excluded. Ultimately, as in Model 11, we find that we can generate substantial risk-adjusted returns when we screen our target portfolios using all three criteria (size, liquidity and leverage). The portfolios achieve CAPM-adjusted returns of 0.9 percent per month (p-value of 0.021), FF3Fadjusted returns of 0.8 per month (p-value of 0.007) and BHARs of between 0.7 and 0.9 percent per month (significant at the one percent level). These results provide evidence to support the use of our portfolio screening strategy. Overall, these results suggest that takeover prediction as an investment strategy is potentially profitable when steps can be taken to mitigate the effects of financially distressed firms within target portfolios. 


\subsection{Additional analyses}

In this section, we perform four additional analyses to explore whether we can even further improve our results. In the first analysis, we consider whether an extended prediction model (i.e., one with more predictive variables) yields better results by reducing type II errors in prediction. In the second, we test whether we can improve model predictive ability, and hence portfolio returns, by using industry-adjusted firm ratios. In the third, we explore whether a multinomial model which predicts targets by method of payment potentially generates higher portfolio abnormal returns. In the final analysis, we investigate whether a hedge strategy (involving the short-selling of distressed firms) can be used to further improve the returns to our portfolios. We discuss these below.

The findings from Table 3 suggest that prediction errors were partly responsible for the poor performance of target portfolios generated from conventional prediction models. In the first analysis, we explore whether the predictive ability of the conventional prediction model can be improved by incorporating variables that have been shown in recent studies to explain takeover likelihood. Following recent M\&A studies, we augment the conventional model by further adding industry concentration (Powell and Yawson, 2007), a block holders dummy (Cremers et al., 2009), price momentum, trading volume, a market sentiment dummy (Brar et al., 2009), and a rumour dummy (Siganos and Papa, 2015) as variables that can potentially explain a firm's takeover likelihood. We eliminate outliers by winsorising price momentum at the $1^{\text {st }}$ and $99^{\text {th }}$ percentiles, but no adjustments are made to the other variables. The hypotheses and their proxies are summarised in Appendix 2. We use these new variables to develop an expanded (augmented) model, which we use to generate new predicted target portfolios. $^{14}$

\footnotetext{
${ }^{14}$ The model parameters for the full sample period are available upon request.
} 
The conventional and augmented models identify similar firms as potential targets, with 77.64 percent of firms predicted as targets by the conventional model also predicted as targets by the augmented model. Nonetheless, the augmented model predicts 3,526 targets over fifteen years, of which only 280 become actual targets - a target concentration of 7.94 percent, compared to the 8.52 percent achieved by the conventional model. This suggests that we do not improve the conventional model's predictive ability by adding the new variables suggested in recent studies.

Next, we explore whether portfolios generated from the augmented model earn riskadjusted returns before and after our suggested strategies are applied. The results are reported in Table 5. We find that the CAPM abnormal return to the portfolio of predicted targets generated by the augmented model is 0.2 percent per month, but insignificant, with a p-value of 0.567 . The BHARs across all benchmarks are not significantly different from zero. We replicate our strategies of sequentially eliminating firms with low Z scores, low market values, high leverage and low liquidity. As shown in Table 5, the augmented model generates lower risk-adjusted returns across all strategies than the conventional model (Table 4). When portfolios are screened by size, liquidity and leverage, it also generates substantial but slightly lower risk-adjusted returns across all models. Overall, these results show that the conventional model performs well and is not substantially improved by including new predictive variables (such as those in Appendix 2). We therefore do not have a clear answer as to how to improve the prediction model so as to reduce the number of type II errors.

[Insert Table 5 around here]

In the second test, we explore whether the predictive ability of the conventional model can be improved by scaling the accounting variables by their industry averages to derive industry-adjusted accounting variables. As noted in Powell (2001), the use of industryrelative ratios can improve data stability in long-run prediction studies. Further, firms that 
'stand-out' from their counterparts in the industry (e.g., by performing comparatively poorly) are perhaps more likely to be targeted for takeover. We find that the predictive ability of the model declines slightly when all firm variables (except dummy variables) are scaled by their industry averages. The industry-adjusted model achieves a slightly lower target concentration of 8.24 percent compared to the 8.52 percent achieved by the conventional model. As shown in Table 6, this lower predictive ability leads to lower returns to target portfolios (Model 1). The returns remain low and insignificant (e.g., CAPM-adjusted returns of 0.3 percent per month, p-value of 0.339) even after screening portfolios for size, liquidity and leverage (Model 2). The decline in CAPM-adjusted abnormal returns from 0.9 percent per month (Table 4, Model 11) is, perhaps, too great to be simply explained by the slight decline in target concentration. Upon further analysis, we find that only 50.63 percent of firms predicted as targets by the conventional model are also predicted as targets by the industry-adjusted conventional model. This suggests that the industry-adjusted model predicts a new set of targets, perhaps those which 'stand-out' from their counterparts but do not perform as well. The result is that the portfolios generated by the industry-adjusted model earn abnormal returns which are not statistically significant at the ten percent level.

\section{[Insert Table 6 around here]}

Prior studies have shown that the returns to targets vary by method of payment, with targets of cash bids typically earning significantly higher announcement returns (Danbolt, 2004). In the third analysis, we test whether we can generate higher abnormal returns from takeover prediction by focusing on potential targets of cash bids. To explore this, we identify the method of payment (stock, cash and mixed) for each of the bids in our sample. This allows us to use existing variables from our conventional model to develop a multinomial model which predicts whether a firm will receive a cash bid, stock bid, mixed pay bid or no bid. In this model, $P_{i t}$ (from equation 1) takes a value of zero if no takeover is announced in a 
period $(t)$; one if a firm (i) is the subject of a takeover where the bidder offers cash as the method of payment; two when the bidder offers stock; and three when the bidder offers a mix of cash and stock in exchange for the target's shares. With the exception of valuation and size, we do not find substantial variability in the financial characteristics of targets of 'cash', 'stock' and 'mixed' methods of payment bids as proxied by our hypotheses. ${ }^{15}$ The results from our multinomial model suggest that targets in cash acquisitions are typically undervalued (low Tobin's Q), while targets in stock acquisitions typically have higher Tobin's Q ratios. These results are consistent with Shleifer and Vishny (2003) and Bi and Gregory (2011). They also support Dong et al.’s (2006) contention that takeovers are driven by bidders who deliberately seek to profit from investor misvaluation by buying undervalued targets for cash or by paying equity for overvalued targets. Consistent with our transaction cost argument (Palepu, 1986; Powell, 2001; Gorton et al., 2009), we also find some evidence suggesting that bidders are likely to offer cash to purchase small targets but are likely to offer stock when bidding for larger targets.

We follow our recursive approach to generate new parameters for this model, predicting targets by method of payment, one year ahead, for the period 1995-2009. Using 'non-target' as our base category in the multinomial regression, we generate probabilities that each firm-year observation in the holdout period will be a 'cash', 'stock' or 'mixed pay' target. We then use our 'cash' takeover probability to rank firms and generate our quintile target portfolios as before. The multinomial model predicting 'cash targets' makes 3,542 predictions over the holdout period (1995-2009), of which 281 (7.93 percent) turn out to be actual targets. The 281 actual targets consist of 215 (6.07 percent) 'cash' targets, 43 (1.21 percent) 'stock’ targets and 23 (0.65 percent) 'mixed pay’ targets. Besides misclassifying non-targets as potential 'cash' targets, the model also misclassifies 'stock' targets and 'mixed

\footnotetext{
15 The parameters of this model for the full sample period are available upon request.
} 
pay’ targets as potential ‘cash’ targets. The ‘cash’ target concentration (6.07 percent), as well as the overall target concentration (7.93 percent), achieved by the multinomial model is lower than the concentration achieved by the conventional model (8.52 percent). As expected, this (slightly) lower predictive ability also translates into (slightly) lower portfolio abnormal returns, as shown in Table 6 (Models 3 and 4). The abnormal returns from this model are about 0.1 percentage points lower than those from the conventional model. The results suggest that the multinomial model is not a substantial improvement on the conventional model.

The results from Table 4 suggest that the returns to target portfolios generated using the conventional model can be improved by screening for size, liquidity and leverage - a process which reduces the proportion of distressed firms in predicted target portfolios. In our final test, we explore whether there are benefits to pursuing a hedge strategy which involves holding the portfolio of screened targets and also short-selling the distressed stocks. It is worth noting that such a strategy might be unimplementable due to the practical difficulty of short-selling some of these small and/or distressed stocks. The results from this analysis are presented in Table 6 (Model 5). We find, to the extent that this is implementable, the hedge strategy yields returns which are slightly higher than those generated by a simple screening strategy. The results from the CAPM and FF3F models are similar (0.9 percent per month), but the market benchmark BHAR from the hedge strategy increases to 1.4 percent per month.

\section{Conclusion}

Several studies have investigated whether abnormal returns can be earned by investing in portfolios of predicted targets. Even without considering the negative impact of bankrupt firms within predicted target portfolios, the results from prior research suggest that the strategy is unlikely to yield consistent returns for investors. We contribute to this 
literature by exploring the challenges of generating abnormal returns from target prediction modelling and identifying ways in which some of these challenges can be mitigated. Our initial results suggest that portfolio returns are contingent on our ability to correctly predict targets, as type II errors within our target portfolio reduce the returns to these portfolios. Nonetheless, by comparing the performance of an augmented and a conventional model, we find that the performance of the prediction model does not improve when we simply expand the number of predictive variables in models.

We attribute some of the poor performance of target portfolios to seemingly unavoidable inefficiencies in the timing of predictions. The fact that targets typically underperform several months prior to bids, and the difficulty of accurately timing predictions (to minimise periods of pre-bid underperformance yet outsmart other market participants), appear to be drawbacks of the strategy. Our results show that qualitative information, such as merger rumours, could potentially be used to screen target portfolios and partly alleviate the timing problem. However, based on our limited dataset of merger rumours, we do not find evidence that target portfolios generate significant risk-adjusted returns when a rumour screen is applied. Nonetheless, this timing issue diminishes but does not eliminate the prospect of earning positive abnormal returns from the target prediction strategy.

Our results also reveal that predicted target portfolios do not earn positive abnormal returns, due to the tendency for a disproportionate number of poorly-performing firms, some of which end up going bankrupt, to be misclassified as expected takeover targets. Given that bankrupt firms tend to be smaller, less liquid and highly leveraged, we show that a simple size, leverage or liquidity screening strategy can be used to mitigate much of the negative effect of bankrupt and distressed firms within target portfolios. We provide evidence that the adoption of this recommended strategy leads to the generation of significant positive abnormal returns of up to 0.9 percent per month. Similar or even slightly higher returns could 
be achieved if one is able to further short-sell these high bankruptcy risk firms. Overall, the results of the study provide a foundation for the development of optimal portfolio strategies for academic and practitioner purposes. 


\section{References}

Agarwal, R. \& Gort, M. (2002), 'Firm and Product Life Cycles and Firm Survival', American Economic Review, Vol. 92, No. 2, pp. 184-190.

Agarwal, V. \& Taffler, R. (2008), 'Comparing the Performance of Market-Based and Accounting-Based Bankruptcy Prediction Models', Journal of Banking \& Finance, Vol. 32, No. 8, pp. 1541-1551.

Agrawal, A. \& Jaffe, J. (2003), 'Do Takeover Targets Underperform? Evidence from Operating and Stock Returns', Journal of Financial and Quantitative Analysis, Vol. 38, No. 4, pp. 721-746.

Ahern, K. R. \& Sosyura, D. (2015), 'Rumor Has It: Sensationalism in Financial Media', Review of Financial Studies, Vol. 28, No. 7, pp. 2050-2093.

Ambrose, B. W. \& Megginson, W. L. (1992), 'The Role of Asset Structure, Ownership Structure, and Takeover Defences in Determining Acquisition Likelihood', Journal of Financial and Quantitative Analysis, Vol. 27, No. 4, pp. 575-589.

Barber, B. M. \& Lyon, J. D. (1997), 'Detecting Long-Run Abnormal Stock Returns: The Empirical Power and Specification of Test Statistics', Journal of Financial Economics, Vol. 43, No. 3, pp. 341-372.

Barnes, P. (1998), 'Can Takeover Targets be Identified by Statistical Techniques?: Some UK Evidence', Journal of the Royal Statistical Society (The Statistician), Vol. 47, No. 4, pp. 573591.

Barnes, P. (1999), 'Predicting UK Takeover Targets: Some Methodological Issues and an Empirical Study', Review of Quantitative Finance and Accounting, Vol. 12, No. 3, pp. 283302.

Barnes, P. (2000), 'The identification of UK Takeover Targets using Published Historical Cost Accounting Data: Some Empirical Evidence Comparing Logit with Linear Discriminant Analysis and Raw Financial Ratios with Industry-Relative Ratios', International Review of Financial Analysis, Vol. 9, No. 2, pp. 147-162.

Bartley, J. W. \& Boardman, C. M. (1990), 'The Relevance of Inflation Adjusted Accounting Data to the Prediction of Corporate Takeovers', Journal of Business Finance \& Accounting, Vol. 17, No. 1, pp. 53-72.

Bhattacharjee, A., Igson, C., Olly, S., \& Kattuman, P. (2009), 'Macroeconomic Instability and Business Exit: Determinants of Failures and Acquisitions of UK Firms', Economica, Vol. 76, pp. 108-131.

Bi, X. G. \& Gregory, A. (2011), 'Stock Market Driven Acquisitions versus the Q Theory of Takeovers: The UK Evidence', Journal of Business Finance \& Accounting, Vol. 38, No. 5-6, pp. 628-656.

Brar, G., Giamouridis, D., \& Liodakis, M. (2009), 'Predicting European Takeover Targets', European Financial Management, Vol. 15, No. 2, pp. 430-450. 
Cahan, R., Luo, F., Alvarez, M., Jussa, J., \& Chen, Z. (2011), 'Signal Processing; Targeting Takeovers', Deutsche Bank Quantitative Strategy, Deutsche Bank Securities Inc, No. 22 August.

Carhart, M. M. (1997), 'On Persistence in Mutual Fund Performance', Journal of Finance, Vol. 52, No. 1, pp. 57-82.

Chou, H., Tian, G. Y. \& Yin, X. (2015), 'Takeover Rumors: Returns and Pricing of Rumoured Targets', International Review of Financial Analysis, Vol. 41, pp. 13-27.

Clark, K. \& Ofek, E. (1994), 'Mergers as a Means of Restructuring Distressed Firms: An Empirical Investigation', Journal of Financial and Quantitative Analysis, Vol. 29, pp. 541565.

Cornett, M. M., Tanyeri, B. A., \& Tehranian, H. (2011), 'The Effect of Merger Anticipation on Bidder and Target Firm Announcement Period Returns', Journal of Corporate Finance, Vol. 17, No. 3, pp. 595-611.

Cremers, K. J. M., Nair, V. B., \& John, K. (2009), 'Takeovers and the Cross-Section of Returns', The Review of Financial Studies, Vol. 22, No. 4, pp. 1409-1445.

Danbolt, J. (2004), 'Target Company Cross-Border Effects in Acquisitions into the UK', European Financial Management, Vol. 10, No. 1, pp. 83-108.

De, S. \& Jindra, J. (2012), 'Why Newly Listed Firms Become Acquisition Targets', Journal of Banking \& Finance, Vol. 36, No. 9, pp. 2616-2631.

DeLong, E. R., DeLong, D. M. \& Clarke-Pearson, D. L. (1988), 'Comparing the Areas Under two or more Correlated Receiver Operating Characteristic Curves: A Nonparametric Approach', Biometrics, Vol. 44, pp. 837-845.

Dong, M., Hirshleifer, D., \& Richardson, S. T. S. (2006), 'Does Investor Misvaluation Drive the Takeover Market?', Journal of Finance, Vol. 61, No. 2, pp. 725-762.

Espahbodi, H. \& Espahbodi, P. (2003), 'Binary Choice Models and Corporate Takeover', Journal of Banking \& Finance, Vol. 27, No. 4, pp. 549-574.

Fama, E. \& French, K. (1992), 'The Cross-Section of Expected Stock Returns', Journal of Finance, Vol. 47, No. 2, pp. 427-465.

Fama, E. \& Jensen, M. (1983), 'Separation of Ownership and Control', Journal of Law and Economics, Vol. 26, No. 2, pp. 227-249.

Franks, J. R. \& Harris, R. S. (1989), 'Shareholder Wealth Effects of Corporate Takeovers: The U.K. Experience 1955-1985', Journal of Financial Economics, Vol. 23, No. 2, pp. 225249.

Gilbert, T., Hrdlicka, C., Kalodimos, C. \& Siegel, S. (2014), 'Daily Data is Bad for Beta: Opacity and Frequency-Dependent Betas', Review of Asset Pricing Studies, Vol. 4, No. 1, pp. 78-117.

Goergen, M. \& Renneboog, L. (2004), 'Shareholder Wealth Effects of European Domestic and Cross-Border Takeover Bids', European Financial Management, Vol. 10, No. 1, pp. 945. 
Gorton, G., Kahl, M., \& Rosen, R. (2009), 'Eat or Be Eaten: A Theory of Mergers and Firm Size', Journal of Finance, Vol. 64, No. 3, pp. 1291-1344.

Gregory, A. \& O’Donohoe, S. (2014), 'Do Cross-border and Domestic Acquisitions differ? Evidence from the acquisition of UK targets', International Review of Financial Analysis, Vol. 31, pp. 61-69.

Gregory, A., Tharyan, R., \& Christidis, A. (2013), 'Constructing and Testing Alternative Versions of the Fama and French and Carhart Models in the UK', Journal of Business Finance \& Accounting, Vol. 40, Nos. 1-2, pp. 172-214.

Hasbrouck, J. (1985), 'The Characteristics of Takeover Targets: q and other Measures', Journal of Banking and Finance, Vol. 9, pp. 351-362.

Jensen, M. C. \& Ruback, R. S. (1983), 'The Market for Corporate Control: The Scientific Evidence', Journal of Financial Economics, Vol. 11, No. 1-4, pp. 5-50.

Jensen, M.C. (1986), 'Agency Costs of Free Cash Flow, Corporate Finance, and Takeovers', American Economic Review, Vol. 76, No. 2, pp. 323-329.

Jindra, J. \& Walkling, R. (2004), 'Speculation Spreads and the Market Pricing of Proposed Acquisitions', Journal of Corporate Finance, Vol. 10, No. 4, pp. 495-526.

Lin, J., Stephens, C. P. \& Wu, Y. (2014), 'Limited Attention, Share Repurchases and Takeover Risks', Journal of Banking and Finance, Vol. 42, pp. 283-301.

Loderer, C. \& Waelchli, U. (2015), 'Corporate Aging and Takeover Risk', Review of Finance, Forthcoming.

Lyon, J., Barber, B. \& Tsai, C. (1999), 'Improved Methods of Tests of Long-horizon Abnormal Stock Returns', Journal of Finance, Vol. 54, No. 1, pp. 165-201.

Manne, H. G. (1965), 'Mergers and the Market for Corporate Control', Journal of Political Economy, Vol. 73, No. 2, pp. 110-120.

Myers, S. C. \& Majluf, N.S. (1984), 'Corporate Financing and Investment Decisions when Firms have Information that Investors do not have', Journal of Financial Economics, Vol. 13, pp. 187-221.

Pakes, A. \& Ericson, R. (1998), 'Empirical Implications of Alternative Models of Firm Dynamics', Journal of Economic Theory, Vol. 79, pp. 1-45.

Palepu, K. G. (1986), 'Predicting Takeover Targets: A Methodological and Empirical Analysis', Journal of Accounting and Economics, Vol. 8, No. 1, pp. 3-35.

Pasiouras, F., Tanna, S., \& Zopounidis, C. (2007) 'The Identification of Acquisition Targets in the EU Banking Industry: An Application of Multicriteria Approaches', International Review of Financial Analysis, Vol. 16, pp. 262-281.

Pastena, V. \& Ruland, W. (1986), 'The Merger/Bankruptcy Alternative', Accounting Review, Vol. 61, pp. 288-301.

Pound, J., \& Zeckhauser, R. (1990), 'Clearly Heard on the Street: The Effect of Takeover Rumors on Stock Prices', Journal of Business, Vol. 63, No. 3, pp. 291-308. 
Powell, R. \& Yawson, A. (2005), 'Industry Aspects of Takeovers and Divestitures: Evidence from the UK', Journal of Banking \& Finance, Vol. 29, No. 2, pp. 3015-3040.

Powell, R. G. \& Yawson, A. (2007), 'Are Corporate Restructuring Events Driven by Common Factors? Implications for Takeover Prediction', Journal of Business Finance \& Accounting, Vol. 34, Nos. 7-8, pp. 1169-1192.

Powell, R. G. (1997), 'Modelling Takeover Likelihood', Journal of Business Finance \& Accounting, Vol. 24, No. 7-8, pp. 1009-1030.

Powell, R. G. (2001), 'Takeover Prediction and Portfolio Performance: A Note', Journal of Business Finance \& Accounting, Vol. 28, Nos. 7-8, pp. 993-1011.

Powell, R. G. (2004), 'Takeover Prediction Models and Portfolio Strategies: A Multinomial Approach', Multinational Finance Journal, Vol. 8, pp. 35-74.

Renneboog, L. \& Trojanowski, G. (2007), 'Control Structures and Payout Policy', Managerial Finance, Vol. 33, No. 1, pp. 43-64.

Rodrigues, B. D. \& Stevenson, M. J. (2013), 'Takeover Prediction Using Forecast Combinations', International Journal of Forecasting, Vol. 29, pp. 628-641.

Sharpe, W. F. (1964), 'Capital Asset Prices: A Theory of Market Equilibrium Under Conditions of Risk', The Journal of Finance, Vol. 19, pp. 425-442.

Shleifer, A. \& Vishny, R. W. (1986), 'Large Shareholders and Corporate Control', The Journal of Political Economy, Vol. 94, No. 3, pp. 461-488.

Shleifer, A. \& Vishny, R. W. (1997), 'A Survey of Corporate Governance', Journal of Finance, Vol. 52, No. 2, pp. 737-783.

Shleifer, A. \& Vishny, R. W. (2003), 'Stock Market Driven Acquisitions', Journal of Financial Economics, Vol. 70, No. 3, pp. 295-311.

Siganos, A. (2013), 'Google Attention and Target Price Run Ups', International Review of Financial Analysis, Vol. 29, pp. 219-226.

Siganos, A. \& Papa, M. (2015), 'FT Coverage and UK Target Price Run-Ups', European Journal of Finance, Vol. 21, No. 12, pp. 1070-1089.

Soares, N. \& Stark, A. W. (2009), 'The Accruals Anomaly: Can Implementable Portfolio Strategies be Developed that are Profitable Net of Transactions Costs in the UK?', Accounting and Business Research, Vol. 39, No. 4, pp. 321-345.

Stulz, R. \& Johnson, H. (1985), 'An Analysis of Secured Debt', Journal of Financial Economics, Vol. 14, pp. 501-521.

Taffler, R. J. (1983), 'The Assessment of Company Solvency and Performance Using A Statistical Model', Accounting and Business Research, Vol. 13, pp. 295-308.

Walter, R. M. (1994), 'The Usefulness of Current Cost Information for Identifying Takeover Targets and Earning Above-Average Stock Returns', Journal of Accounting, Auditing \& Finance, Vol. 9, No. 2, pp. 349-377. 


\section{Appendix 1}

\section{Hypotheses, proxies and constituent DataStream variables}

\begin{tabular}{|l|l|l|}
\hline Hypotheses & Proxies (Exp. sign) & DataStream codes/Data source \\
\hline \multirow{2}{*}{ Inefficient management } & ROCE (-) & wc01250, wc03998 \\
\cline { 2 - 3 } & AER (-) & RI (Firm and FTSE ALL Share index) \\
\hline Undervaluation & Tobin's Q (+) & wc03501, wc02649, NOSH, UP \\
\hline \multirow{4}{*}{$\begin{array}{l}\text { Growth-resource } \\
\text { mismatch }\end{array}$} & SGrowth (+/-) & wc01001 \\
\cline { 2 - 3 } & Liquidity (+/-) & wc02001, wc02999 \\
\cline { 2 - 3 } & Leverage (+/-) & wc03255, wc03995 \\
\cline { 2 - 3 } & GRDummy (+) & wc01001, wc02001, wc02999, wc03255, wc03995 \\
\hline Industry disturbance & IDDummy (+) & SIC codes \\
\hline Firm size & Firm size (-) & wc02999 \\
\hline Free cash flow & FCF (+) & wc04860, wc04601, wc02999 \\
\hline Tangible assets & Tangibility (+) & wc02501, wc02999 \\
\hline Firm age & Firm age (-) & wc18273 \\
\hline
\end{tabular}

Notes:

This table presents the constituent DataStream variables used to develop proxies for the hypotheses. The proxies for these hypotheses, together with their expected signs, are shown in the second column. ROCE is the ratio of EBITDA to total capital employed. AER (average excess returns) is computed as a firm's average monthly excess return over the market (FTSE All Share) return for the year to June. Tobin's Q is the ratio of market value to book value of assets. SGrowth (sales growth) is the percentage of change in total revenue from the previous period. Liquidity is the ratio of cash and short-term investments to total assets. Leverage is the firm's debt to equity ratio. GRDummy takes a value of one when there is a mismatch between a firm's growth opportunities and its resources, and a value of zero otherwise. IDDummy (industry disturbance dummy) takes a value of one if a takeover occurs in a firm's industry, and a value of zero otherwise. Firm size is the natural log of a firm's total assets. FCF is the ratio of free cash flow (operating cash flow minus capital investments) to total assets. Tangibility is the ratio of tangible assets (property, plant and equipment) to total assets. Firm age is the number of years since incorporation. The hypothesised sign is shown in parentheses. Data is obtained from Thomson DataStream and OneBanker databases. 


\section{Appendix 2}

Additional variables in the augmented model

\begin{tabular}{|c|c|c|c|}
\hline Hypothesis & Rationale & Proxy & Reference \\
\hline $\begin{array}{l}\text { Industry } \\
\text { Concentration }\end{array}$ & $\begin{array}{l}\text { Competition in product } \\
\text { markets (i.e., low } \\
\text { industry concentration) } \\
\text { is especially costly for } \\
\text { inefficiently managed } \\
\text { firms, as it leads to } \\
\text { elimination, possibly } \\
\text { through takeovers. }\end{array}$ & $\begin{array}{l}\text { Herfindahl-Hirschman } \\
\text { index; sum of the squared } \\
\text { market shares (proxied by } \\
\text { total revenues) of all listed } \\
\text { firms in the industry. }\end{array}$ & $\begin{array}{l}\text { Fama and Jensen, } \\
\text { 1983; Shleifer } \\
\text { and Vishny, } \\
\text { 1997; Powell and } \\
\text { Yawson, 2005, } \\
\text { 2007. }\end{array}$ \\
\hline Block holders & $\begin{array}{l}\text { Large shareholders } \\
\text { facilitate takeovers as } \\
\text { they can split gains on } \\
\text { their own shares with the } \\
\text { bidder. }\end{array}$ & $\begin{array}{l}\text { Dummy which takes a } \\
\text { value of one if a firm has a } \\
\text { significant shareholder } \\
\text { (i.e., an institutional } \\
\text { investor holding five } \\
\text { percent or more of the } \\
\text { firm's shares) in the } 90 \\
\text { trading days before June of } \\
\text { each year, and a value of } \\
\text { zero otherwise. }\end{array}$ & $\begin{array}{l}\text { Shleifer and } \\
\text { Vishny, 1986; } \\
\text { Cremers et al., } \\
2009 .\end{array}$ \\
\hline $\begin{array}{l}\text { Price } \\
\text { momentum and } \\
\text { trading volume }\end{array}$ & $\begin{array}{l}\text { Short-term price } \\
\text { momentum and trading } \\
\text { volume captures active } \\
\text { trading in takeover } \\
\text { targets prior to takeover } \\
\text { bids. }\end{array}$ & $\begin{array}{l}\text { Price momentum is the t- } \\
\text { statistic of a trend line } \\
\text { slope fitted to logged daily } \\
\text { stock prices over the } 90 \\
\text { trading days before June of } \\
\text { each year. Trading volume } \\
\text { is the proportion of } \\
\text { outstanding shares traded } \\
\text { over the } 90 \text { trading days to } \\
\text { June each year. }\end{array}$ & Brar et al., 2009. \\
\hline $\begin{array}{l}\text { Market } \\
\text { sentiment }\end{array}$ & $\begin{array}{l}\text { A firm might have the } \\
\text { characteristics of a target } \\
\text { but might not receive a } \\
\text { bid due to poor market } \\
\text { conditions or economic } \\
\text { sentiment. }\end{array}$ & $\begin{array}{l}\text { Dummy which takes a } \\
\text { value of one when the } \\
\text { FTSE ALL share index } \\
\text { reports a positive return in } \\
\text { each year to June, and a } \\
\text { value of zero otherwise. }\end{array}$ & Brar et al., 2009. \\
\hline $\begin{array}{l}\text { Merger } \\
\text { rumours }\end{array}$ & $\begin{array}{l}\text { A substantial number of } \\
\text { takeovers are preceded } \\
\text { by rumours; these } \\
\text { rumours explain part of } \\
\text { the documented pre-bid } \\
\text { target price run-up. }\end{array}$ & $\begin{array}{l}\text { Rumour dummy takes a } \\
\text { value of one if a merger bid } \\
\text { is preceded by a rumour, } \\
\text { and a value of zero } \\
\text { otherwise. }\end{array}$ & $\begin{array}{l}\text { Jindra and } \\
\text { Walking, 2004; } \\
\text { Siganos, 2013; } \\
\text { Siganos and } \\
\text { Papa, 2015; } \\
\text { Pound and } \\
\text { Zeckhauser, } \\
1990 .\end{array}$ \\
\hline
\end{tabular}


Table 1

Descriptive statistics

\begin{tabular}{|c|c|c|c|c|c|c|c|}
\hline \multirow[b]{2}{*}{ Variable } & \multicolumn{2}{|c|}{ Full Sample } & \multicolumn{2}{|c|}{ Targets } & \multicolumn{2}{|c|}{ Non-targets } & \multirow{2}{*}{$\begin{array}{l}\text { Difference } \\
\text {-value }\end{array}$} \\
\hline & Mean & $S D$ & Mean & $S D$ & Mean & $S D$ & \\
\hline ROCE & 0.118 & 0.544 & 0.118 & 0.544 & 0.068 & 0.725 & $(0.007)^{* * *}$ \\
\hline$A E R$ & -0.018 & 0.048 & -0.018 & 0.048 & -0.012 & 0.051 & $(0.000)^{* * *}$ \\
\hline Tobin's $Q$ & 1.666 & 1.266 & 1.666 & 1.266 & 1.860 & 1.865 & $(0.000)^{* * *}$ \\
\hline Sales growth & 0.307 & 1.300 & 0.307 & 1.300 & 0.330 & 1.332 & $(0.513)$ \\
\hline Liquidity & 0.122 & 0.159 & 0.122 & 0.159 & 0.144 & 0.181 & $(0.000)^{* * *}$ \\
\hline Leverage & 0.628 & 1.710 & 0.628 & 1.710 & 0.512 & 1.642 & $(0.005)^{* * *}$ \\
\hline GR mismatch & 0.247 & 0.431 & 0.247 & 0.431 & 0.263 & 0.440 & $(0.165)$ \\
\hline Disturbance & 0.203 & 0.402 & 0.203 & 0.402 & 0.210 & 0.408 & $(0.474)$ \\
\hline Firm size & 18.169 & 1.795 & 18.169 & 1.795 & 17.813 & 2.192 & $(0.000)^{* * *}$ \\
\hline Free cash flow & 0.000 & 0.161 & 0.000 & 0.161 & -0.054 & 0.311 & $(0.000)^{* * *}$ \\
\hline Tangible assets & 0.341 & 0.264 & 0.341 & 0.264 & 0.321 & 0.250 & $(0.001)^{* * *}$ \\
\hline Firm age & 30.465 & 31.701 & 30.465 & 31.701 & 31.904 & 32.746 & $(0.089) *$ \\
\hline
\end{tabular}

\section{Notes:}

This table reports descriptive statistics of predictive variables for the full sample, all targets and all non-targets. ROCE is the ratio of EBITDA to total capital employed. AER (average excess returns) is computed as a firm's average monthly excess return over the market (FTSE All Share) return for the year to June. Tobin's Q is the ratio of market value to book value of assets. SGrowth (sales growth) is the percentage of change in total revenue from the previous period. Liquidity is the ratio of cash and short-term investments to total assets. Leverage is the firm's debt to equity ratio. GRDummy takes a value of one when there is a mismatch between a firm's growth opportunities and its resources, and a value of zero otherwise. IDDummy (industry disturbance dummy) takes a value of one if a takeover occurs in a firm's industry and a value of zero otherwise. Firm size is the natural log of a firm's total assets. FCF is the ratio of free cash flow (operating cash flow minus capital investments) to total assets. Tangibility is the ratio of tangible assets (property, plant and equipment) to total assets. Firm age is the number of years since incorporation. The p-value for the difference in variable means for targets and non-targets is shown in the last column. * and *** indicate significance at the $10 \%$ and $1 \%$ levels, respectively. 
Table 2

Determinants of firm takeover likelihood

\begin{tabular}{lll}
\hline & Coefficient & $p$-value \\
ROCE & 0.087 & $(0.171)$ \\
AER & $-3.552^{* * *}$ & $(0.000)$ \\
Tobin's Q & $-0.062^{* *}$ & $(0.011)$ \\
Sales growth & 0.002 & $(0.922)$ \\
Liquidity & $-0.389^{*}$ & $(0.065)$ \\
Leverage & 0.025 & $(0.134)$ \\
GR mismatch & 0.018 & $(0.789)$ \\
Disturbance & -0.057 & $(0.421)$ \\
Firm size & 0.020 & $(0.181)$ \\
Free cash flow & $0.973^{* * *}$ & $(0.000)$ \\
Tangible assets & $0.389^{* * *}$ & $(0.001)$ \\
Firm age & $-0.004^{* * *}$ & $(0.000)$ \\
Constant & $-2.840^{* * *}$ & $(0.000)$ \\
\hline Observations & 18,794 & \\
McFadden's Adj R2 & 0.011 & \\
Cragg \& Uhler's R2 & 0.017 & \\
LR Chi2 & $128.558^{* * *}$ & $(0.000)$ \\
\hline Notr:
\end{tabular}

\footnotetext{
Notes:

This table reports the coefficient estimates of the conventional binomial logit model estimated using our full data set (1988-2009). For predictions, the model coefficients are re-estimated in a recursive manner and used to predict targets one year in advance. The dependent variable in the model is takeover probability (bivariate), and the independent variables are the prediction hypotheses. ROCE is the ratio of EBITDA to total capital employed. AER (average excess returns) is computed as a firm's average monthly excess return over the market (FTSE All Share) return for the year to June. Tobin's $Q$ is the ratio of market value to book value of assets. SGrowth (sales growth) is the percentage of change in total revenue from the previous period. Liquidity is the ratio of cash and short-term investments to total assets. Leverage is the firm's debt to equity ratio. GRDummy takes a value of one when there is a mismatch between a firm's growth opportunities and its resources, and a value of zero otherwise. IDDummy (industry disturbance dummy) takes a value of one if a takeover occurs in a firm's industry, and a value of zero otherwise. Firm size is the natural log of a firm's total assets. FCF is the ratio of free cash flow (operating cash flow minus capital investments) to total assets. Tangible assets is the ratio of property, plant and equipment to total assets. Firm age is the number of years since incorporation. P-values (corrected for clustering by firm and year) are presented in parentheses. $*, * *$ and ${ }^{* * *}$ indicate significance at the $10 \%, 5 \%$ and $1 \%$ levels, respectively.
} 
Table 3

Risk-adjusted returns

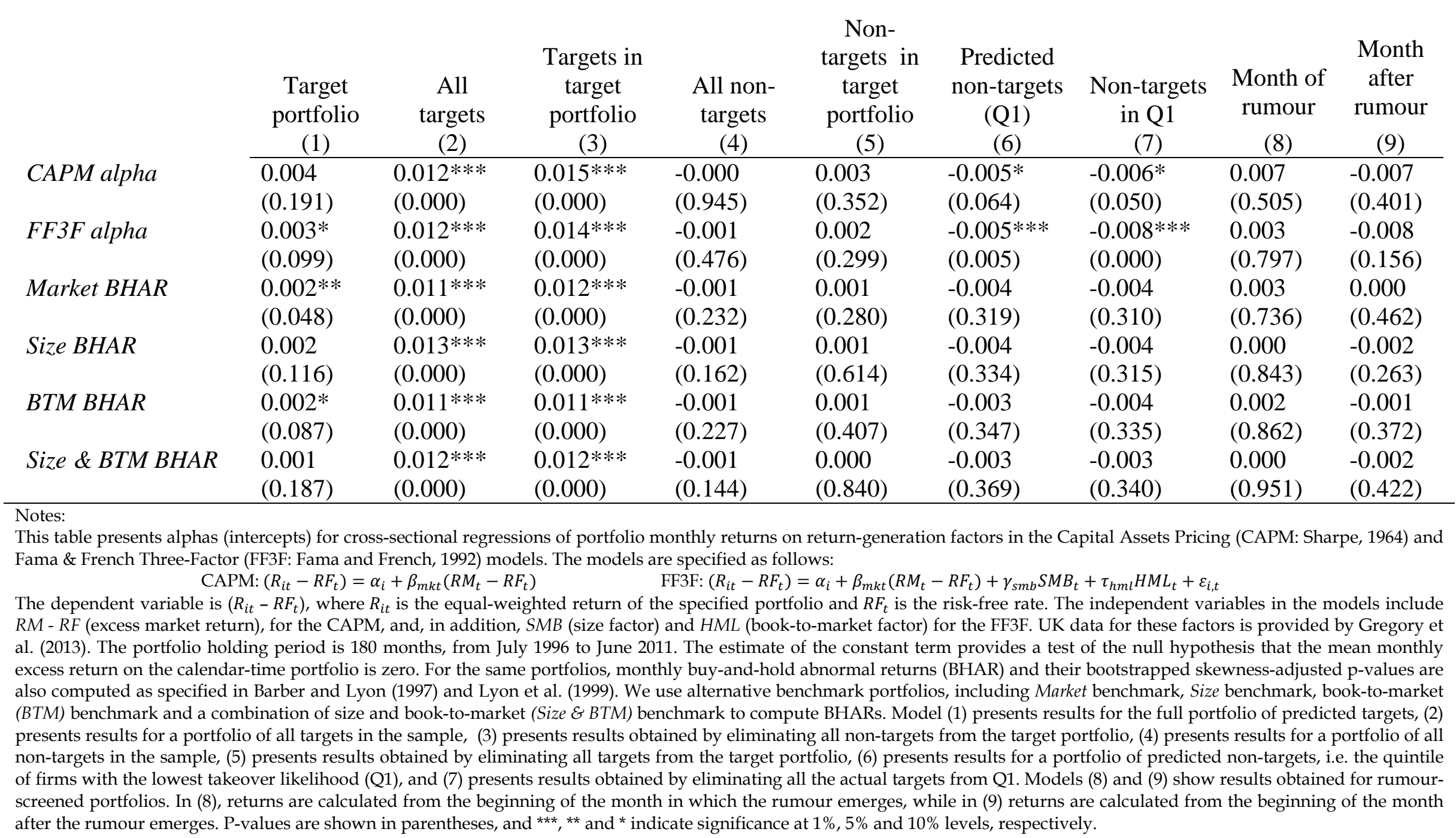


Table 4

Suggested strategies and risk-adjusted returns to portfolios of predicted targets (PTs)

\begin{tabular}{|c|c|c|c|c|c|c|c|c|c|c|c|}
\hline & $\begin{array}{l}\text { Excl. PTs } \\
\text { which go } \\
\text { bankrupt }\end{array}$ & $\begin{array}{l}\text { Excl. PTs } \\
\text { with Z } \\
\text { Scores } \\
\text { Q1 }\end{array}$ & $\begin{array}{c}\text { Excl. PTs } \\
\text { with Z } \\
\text { Scores } \\
\text { Q1, Q2 }\end{array}$ & $\begin{array}{l}\text { Value- } \\
\text { weighted } \\
\text { returns of } \\
\text { PTs }\end{array}$ & $\begin{array}{l}\text { Excl. } \\
\text { PTs } \\
\text { with } \\
\text { MV } \\
\text { Q1 }\end{array}$ & $\begin{array}{l}\text { Excl. } \\
\text { PTs with } \\
\text { MV } \\
\text { Q1, Q2 }\end{array}$ & $\begin{array}{l}\text { Excl. PTs } \\
\text { with } \\
\text { leverage } \\
\text { Q5 }\end{array}$ & $\begin{array}{l}\text { Excl. PTs } \\
\text { with } \\
\text { leverage } \\
\text { Q4, Q5 }\end{array}$ & $\begin{array}{l}\text { Excl. PTs } \\
\text { with } \\
\text { liquidity } \\
\text { Q1 }\end{array}$ & $\begin{array}{l}\text { Excl. PTs } \\
\text { with } \\
\text { liquidity } \\
\text { Q1, Q2 }\end{array}$ & $\begin{array}{l}\text { Strategies } \\
(6),(8) \& \\
(10) \\
\text { combined }\end{array}$ \\
\hline & (1) & $(2)$ & (3) & (4) & (5) & $(6)$ & (7) & (8) & (9) & (10) & $(11)$ \\
\hline CAPM alpha & $\begin{array}{l}0.006^{* *} \\
(0.024)\end{array}$ & $\begin{array}{l}0.005^{*} \\
(0.091)\end{array}$ & $\begin{array}{l}0.006^{*} \\
(0.052)\end{array}$ & $\begin{array}{l}-0.001 * * \\
(0.013)\end{array}$ & $\begin{array}{l}0.004 \\
(0.264)\end{array}$ & $\begin{array}{l}0.005 \\
(0.105)\end{array}$ & $\begin{array}{l}0.005^{* *} \\
(0.049)\end{array}$ & $\begin{array}{l}0.007 * * \\
(0.013)\end{array}$ & $\begin{array}{l}0.005 \\
(0.103)\end{array}$ & $\begin{array}{l}0.006^{*} \\
(0.053)\end{array}$ & $\begin{array}{l}0.009 * * \\
(0.021)\end{array}$ \\
\hline FF3F alpha & $\begin{array}{l}0.005^{* * *} \\
(0.001)\end{array}$ & $\begin{array}{l}0.004^{* *} \\
(0.024)\end{array}$ & $\begin{array}{l}0.005^{* * * *} \\
(0.009)\end{array}$ & $\begin{array}{l}-0.001 * * * \\
(0.009)\end{array}$ & $\begin{array}{l}0.002 \\
(0.212)\end{array}$ & $\begin{array}{l}0.004^{* *} \\
(0.044)\end{array}$ & $\begin{array}{l}0.005^{* * * *} \\
(0.009)\end{array}$ & $\begin{array}{l}0.007 * * * \\
(0.001)\end{array}$ & $\begin{array}{l}0.004 * * \\
(0.031)\end{array}$ & $\begin{array}{l}0.005^{* *} \\
(0.012)\end{array}$ & $\begin{array}{l}0.008 * * * \\
(0.007)\end{array}$ \\
\hline Market BHAR & $\begin{array}{l}0.004^{* * *} \\
(0.008)\end{array}$ & $\begin{array}{l}0.004^{* * *} \\
(0.000)\end{array}$ & $\begin{array}{l}0.003 * * * \\
(0.001)\end{array}$ & $\begin{array}{l}0.001 * * * \\
(0.006)\end{array}$ & $\begin{array}{l}0.002^{*} \\
(0.080)\end{array}$ & $\begin{array}{l}0.005^{* * *} \\
(0.000)\end{array}$ & $\begin{array}{l}0.004^{* * * *} \\
(0.006)\end{array}$ & $\begin{array}{l}0.004^{* *} \\
(0.010)\end{array}$ & $\begin{array}{l}0.003^{* * *} \\
(0.003)\end{array}$ & $\begin{array}{l}0.005^{* * * *} \\
(0.001)\end{array}$ & $\begin{array}{l}0.009 * * * \\
(0.001)\end{array}$ \\
\hline Size BHAR & $\begin{array}{l}0.003^{* *} \\
(0.043)\end{array}$ & $\begin{array}{l}0.003^{* * * *} \\
(0.000)\end{array}$ & $\begin{array}{l}0.003^{* * * *} \\
(0.002)\end{array}$ & $\begin{array}{l}0.001^{* *} \\
(0.021)\end{array}$ & $\begin{array}{l}0.001 \\
(0.263)\end{array}$ & $\begin{array}{l}0.003^{* * *} \\
(0.007)\end{array}$ & $\begin{array}{l}0.003^{* *} \\
(0.011)\end{array}$ & $\begin{array}{l}0.004^{* *} \\
(0.012)\end{array}$ & $\begin{array}{l}0.003^{* * *} \\
(0.009)\end{array}$ & $\begin{array}{l}0.004^{* * * *} \\
(0.004)\end{array}$ & $\begin{array}{l}0.007 * * * \\
(0.006)\end{array}$ \\
\hline BTM BHAR & $\begin{array}{l}0.004^{* *} \\
(0.014)\end{array}$ & $\begin{array}{l}0.003^{* * * *} \\
(0.001)\end{array}$ & $\begin{array}{l}0.003^{* * * *} \\
(0.007)\end{array}$ & $\begin{array}{l}0.001^{* * * *} \\
(0.004)\end{array}$ & $\begin{array}{l}0.002 \\
(0.133)\end{array}$ & $\begin{array}{l}0.004^{* * * *} \\
(0.000)\end{array}$ & $\begin{array}{l}0.003 * * \\
(0.013)\end{array}$ & $\begin{array}{l}0.004 * * \\
(0.019)\end{array}$ & $\begin{array}{l}0.003^{* * *} \\
(0.005)\end{array}$ & $\begin{array}{l}0.005^{* * * *} \\
(0.001)\end{array}$ & $\begin{array}{l}0.008^{* * * *} \\
(0.003)\end{array}$ \\
\hline $\begin{array}{l}\text { Size \& BTM } \\
\text { BHAR }\end{array}$ & $\begin{array}{l}0.002 \\
(0.163)\end{array}$ & $\begin{array}{l}0.002 * * * \\
(0.005)\end{array}$ & $\begin{array}{l}0.002 * * * \\
(0.006)\end{array}$ & $\begin{array}{l}0.001^{* *} \\
(0.046)\end{array}$ & $\begin{array}{l}0.001 \\
(0.598)\end{array}$ & $\begin{array}{l}0.002 * * \\
(0.032)\end{array}$ & $\begin{array}{l}0.003 * * \\
(0.011)\end{array}$ & $\begin{array}{l}0.004 * * \\
(0.012)\end{array}$ & $\begin{array}{l}0.002 * * \\
(0.020)\end{array}$ & $\begin{array}{l}0.004^{* * *} \\
(0.007)\end{array}$ & $\begin{array}{l}0.007 * * * \\
(0.009)\end{array}$ \\
\hline
\end{tabular}

This table presents alphas (intercepts) for cross-sectional regressions of portfolio monthly returns on return-generation factors in the Capital Assets Pricing (CAPM: Sharpe, 1964) and Fama \& French Three-Factor (FF3F: Fama and French, 1992) models. The models are specified as follows:

$$
\text { CAPM: }\left(R_{i t}-R F_{t}\right)=\alpha_{i}+\beta_{m k t}\left(R M_{t}-R F_{t}\right) \quad \text { FF3F: }\left(R_{i t}-R F_{t}\right)=\alpha_{i}+\beta_{m k t}\left(R M_{t}-R F_{t}\right)+\gamma_{s m b} S M B_{t}+\tau_{h m l} H M L_{t}+\varepsilon_{i, t}
$$

The dependent variable is $\left(R_{i t}-R F_{t}\right)$, where $R_{i t}$ is the equal-weighted return of the specified portfolio and $R F_{t}$ is the risk-free rate. The independent variables in the models include $R M$ - RF (excess market return), for the CAPM, and, in addition, SMB (size factor) and HML (book-to-market factor) for the FF3F. UK data for these factors is provided by Gregory et al. (2013). The portfolio holding period is 180 months, from July 1996 to June 2011. The estimate of the constant term provides a test of the null hypothesis that the mean monthly excess return on the calendar-time portfolio is zero. For the same portfolios, monthly buy-and-hold abnormal returns (BHAR) and their bootstrapped skewness-adjusted p-values are also computed as specified in Barber and Lyon (1997) and Lyon et al. (1999). We use alternative benchmark portfolios, including Market benchmark, Size benchmark, book-to-market (BTM) benchmark and a combination of size and book-to-market (Size E BTM) benchmark to compute BHARs. Model (1) shows the returns to target portfolios when all actual bankrupt firms are excluded from target portfolios (TPs). Models (2) and (3) show results when firms with Taffler Z scores in the first, then first and second, quintile(s), respectively (i.e., low Taffler Z scores), are excluded from TPs. Model (4) shows results when predicted targets are value-weighted when forming TPs. Models (5) and (6) show results when firms with market capitalisation in the first, then first and second, quintile(s), respectively, are excluded from TPs. Models (7) and (8) show results when firms with leverage in the fifth, then fourth and fifth, quintile(s), respectively, are excluded. Models (9) and (10) show results when firms with liquidity in the first, then first and second, quintile(s), respectively, are excluded. In Model (11), we exclude firms with size quintiles 1 and 2, liquidity quintiles 1 and 2, and leverage quintiles 4 and 5 . P-values are shown in parentheses, and ***,** and * indicate significance at $1 \%, 5 \%$ and $10 \%$ levels, respectively. 
Table 5

Suggested strategies and risk-adjusted returns to portfolios of predicted targets (PTs) - Augmented model

\begin{tabular}{|c|c|c|c|c|c|c|c|c|}
\hline & $\begin{array}{c}\text { Target } \\
\text { portfolio } \\
\text { (1) }\end{array}$ & $\begin{array}{c}\text { Excl. PTs } \\
\text { which go } \\
\text { bankrupt } \\
\text { (2) }\end{array}$ & $\begin{array}{c}\text { Excl. PTs } \\
\text { with Z } \\
\text { Scores } \\
\text { Q1, Q2 } \\
\text { (3) }\end{array}$ & $\begin{array}{c}\text { Value-weighted } \\
\text { stock returns of } \\
\text { PTs } \\
\text { (4) }\end{array}$ & $\begin{array}{c}\text { Excl. PTs } \\
\text { with MV } \\
\text { Q1, Q2 } \\
\text { (5) }\end{array}$ & $\begin{array}{c}\text { Excl. PTs with } \\
\text { leverage Q4, } \\
\text { Q5 } \\
(6)\end{array}$ & $\begin{array}{c}\text { Excl. PTs with } \\
\text { liquidity Q1, } \\
\text { Q2 } \\
(7)\end{array}$ & $\begin{array}{l}\text { Strategies } \\
\text { (5), (6) \& (7) } \\
\text { combined } \\
\text { (8) }\end{array}$ \\
\hline CAPM alpha & $\begin{array}{l}0.002 \\
(0.567)\end{array}$ & $\begin{array}{l}0.004 \\
(0.126)\end{array}$ & $\begin{array}{l}0.004 \\
(0.195)\end{array}$ & $\begin{array}{l}-0.003^{* * * *} \\
(0.000)\end{array}$ & $\begin{array}{l}0.004^{* * * *} \\
(0.000)\end{array}$ & $\begin{array}{l}0.005^{*} \\
(0.084)\end{array}$ & $\begin{array}{l}0.005 \\
(0.144)\end{array}$ & $\begin{array}{l}0.008^{* *} \\
(0.042)\end{array}$ \\
\hline FF3F alpha & $\begin{array}{l}0.001 \\
(0.686)\end{array}$ & $\begin{array}{l}0.003^{* *} \\
(0.041)\end{array}$ & $\begin{array}{l}0.003 \\
(0.111)\end{array}$ & $\begin{array}{l}-0.003^{* * *} \\
(0.000)\end{array}$ & $\begin{array}{l}0.002 \\
(0.228)\end{array}$ & $\begin{array}{l}0.004 * * \\
(0.028)\end{array}$ & $\begin{array}{l}0.004 * \\
(0.070)\end{array}$ & $\begin{array}{l}0.007 * * \\
(0.017)\end{array}$ \\
\hline Market BHAR & $\begin{array}{l}-0.000 \\
(0.873)\end{array}$ & $\begin{array}{l}0.004^{* * *} \\
(0.000)\end{array}$ & $\begin{array}{l}0.002 * * \\
(0.035)\end{array}$ & $\begin{array}{l}0.000 \\
(0.888)\end{array}$ & $\begin{array}{l}0.003 * * \\
(0.012)\end{array}$ & $\begin{array}{l}0.002 \\
(0.205)\end{array}$ & $\begin{array}{l}0.003 * * \\
(0.023)\end{array}$ & $\begin{array}{l}0.007 * * \\
(0.011)\end{array}$ \\
\hline Size BHAR & $\begin{array}{l}-0.000 \\
(0.669)\end{array}$ & $\begin{array}{l}0.004 * * * \\
(0.000)\end{array}$ & $\begin{array}{l}0.001^{* *} \\
(0.037)\end{array}$ & $\begin{array}{l}0.000 \\
(0.803)\end{array}$ & $\begin{array}{l}0.001 \\
(0.201)\end{array}$ & $\begin{array}{l}0.002 \\
(0.177)\end{array}$ & $\begin{array}{l}0.002^{*} \\
(0.068)\end{array}$ & $\begin{array}{l}0.005^{* *} \\
(0.038)\end{array}$ \\
\hline BTM BHAR & $\begin{array}{l}-0.000 \\
(0.725)\end{array}$ & $\begin{array}{l}0.004^{* * *} \\
(0.000)\end{array}$ & $\begin{array}{l}0.001 \\
(0.103)\end{array}$ & $\begin{array}{l}0.000 \\
(0.837)\end{array}$ & $\begin{array}{l}0.003^{* *} \\
(0.017)\end{array}$ & $\begin{array}{l}0.002 \\
(0.284)\end{array}$ & $\begin{array}{l}0.003^{* *} \\
(0.022)\end{array}$ & $\begin{array}{l}0.006^{* *} \\
(0.024)\end{array}$ \\
\hline $\begin{array}{l}\text { Size \& BTM } \\
\text { BHAR }\end{array}$ & $\begin{array}{l}-0.000 \\
(0.764)\end{array}$ & $\begin{array}{l}0.003 * * * \\
(0.000)\end{array}$ & $\begin{array}{l}0.001 * \\
(0.055)\end{array}$ & $\begin{array}{l}0.000 \\
(0.934)\end{array}$ & $\begin{array}{l}0.001 \\
(0.239)\end{array}$ & $\begin{array}{l}0.002 \\
(0.115)\end{array}$ & $\begin{array}{l}0.002 * \\
(0.087)\end{array}$ & $\begin{array}{l}0.005 * * \\
(0.039)\end{array}$ \\
\hline
\end{tabular}

Notes:

This table presents alphas (intercepts) for cross-sectional regressions of portfolio monthly returns on return-generation factors in the Capital Assets Pricing (CAPM: Sharpe, 1964) and Fama \& French Three-Factor (FF3F: Fama and French, 1992) models. The models are specified as follows: CAPM: $\left(R_{i t}-R F_{t}\right)=\alpha_{i}+\beta_{m k t}\left(R M_{t}-R F_{t}\right)$

FF3F: $\left(R_{i t}-R F_{t}\right)=\alpha_{i}+\beta_{m k t}\left(R M_{t}-R F_{t}\right)+\gamma_{s m b} S M B_{t}+\tau_{h m l} H M L_{t}+\varepsilon_{i, t}$

The dependent variable is $\left(R_{i t}-R F_{t}\right)$, where $R_{i t}$ is the equal-weighted return of the specified portfolio and $R F_{t}$ is the risk-free rate. The independent variables in the models include $R M$ $R F$ (excess market return), for the CAPM, and, in addition, SMB (size factor) and HML (book-to-market factor) for the FF3F. UK data for these factors is provided by Gregory et al. (2013). The portfolio holding period is 180 months, from July 1996 to June 2011. The estimate of the constant term provides a test of the null hypothesis that the mean monthly excess return on the calendar-time portfolio is zero. For the same portfolios, monthly buy-and-hold abnormal returns (BHAR) and their bootstrapped skewness-adjusted p-values are also computed as specified in Barber and Lyon (1997) and Lyon et al. (1999). We use alternative benchmark portfolios, including Market benchmark, Size benchmark, book-to-market (BTM) benchmark and a combination of size and book-to-market (Size \& BTM) benchmark to compute BHARs. Model (1) presents results obtained for the augmented model. Model (2) shows the returns to the target portfolios when all actual bankrupt firms are excluded from target portfolios (TPs). Model (3) shows results when firms with Taffler $Z$ scores in the first and second quintiles (i.e., low Taffler Z scores) are excluded from TPs. Model (4) shows results when predicted targets are value-weighted when forming TPs. Model (5) shows results when firms with market capitalisation in the first and second quintiles are excluded from TPs. Model (6) shows results when firms with leverage in the fourth and fifth quintiles are excluded. Model (7) shows results when firms with liquidity in the first, then first and second, quintile(s), respectively, are excluded. In Model (8), we exclude firms with size quintiles 1 and 2, liquidity quintiles 1 and 2 , and leverage quintiles 4 and 5 . P-values are shown in parentheses, and ${ }^{* * *},{ }^{* *}$ and * indicate significance at $1 \%, 5 \%$ and $10 \%$ levels, respectively. 


\section{Table 6}

\section{Additional analysis: Risk-adjusted returns to alternative strategies}

\begin{tabular}{|c|c|c|c|c|c|}
\hline & \multicolumn{2}{|c|}{$\begin{array}{c}\text { Industry-adjusted } \\
\text { Model } \\
\end{array}$} & \multicolumn{2}{|c|}{$\begin{array}{l}\text { Multinomial Model } \\
\text { (Cash) }\end{array}$} & \multirow{2}{*}{$\begin{array}{l}\begin{array}{l}\text { Hedge } \\
\text { strategy }\end{array} \\
\text { Screened } \\
\text { portfolio } \\
\quad(5)\end{array}$} \\
\hline & $\begin{array}{c}\text { Target } \\
\text { portfolio } \\
(1)\end{array}$ & $\begin{array}{c}\text { Screened } \\
\text { portfolio } \\
(2)\end{array}$ & $\begin{array}{c}\text { Target } \\
\text { portfolio } \\
(3)\end{array}$ & $\begin{array}{c}\text { Screened } \\
\text { portfolio } \\
(4)\end{array}$ & \\
\hline CAPM alpha & $\begin{array}{l}0.001 \\
(0.604)\end{array}$ & $\begin{array}{l}0.003 \\
(0.339)\end{array}$ & $\begin{array}{l}0.003 \\
(0.260)\end{array}$ & $\begin{array}{l}0.008 * * \\
(0.044)\end{array}$ & $\begin{array}{l}0.009 * * \\
(0.019)\end{array}$ \\
\hline FF3F alpha & $\begin{array}{l}0.000 \\
(0.915)\end{array}$ & $\begin{array}{l}0.002 \\
(0.403)\end{array}$ & $\begin{array}{l}0.002 \\
(0.202)\end{array}$ & $\begin{array}{l}0.006 * * \\
(0.018)\end{array}$ & $\begin{array}{l}0.009 * * \\
(0.020)\end{array}$ \\
\hline Market BHAR & $\begin{array}{l}-0.000 \\
(0.829)\end{array}$ & $\begin{array}{l}0.002 \\
(0.285)\end{array}$ & $\begin{array}{l}0.001 \\
(0.287)\end{array}$ & $\begin{array}{l}0.007 * * * \\
(0.002)\end{array}$ & $\begin{array}{l}0.014 * * * \\
(0.000)\end{array}$ \\
\hline Size BHAR & $\begin{array}{l}-0.001 \\
(0.254)\end{array}$ & $\begin{array}{l}0.001 \\
(0.668)\end{array}$ & $\begin{array}{l}0.001 \\
(0.317)\end{array}$ & $\begin{array}{l}0.006^{* * *} \\
(0.009)\end{array}$ & $\begin{array}{l}0.010 * * * \\
(0.000)\end{array}$ \\
\hline BTM BHAR & $\begin{array}{l}-0.000 \\
(0.611)\end{array}$ & $\begin{array}{l}0.002 \\
(0.327)\end{array}$ & $\begin{array}{l}0.001 \\
(0.452)\end{array}$ & $\begin{array}{l}0.007 * * * \\
(0.006)\end{array}$ & $\begin{array}{l}0.013^{* * *} \\
(0.000)\end{array}$ \\
\hline Size \& BTM BHAR & $\begin{array}{l}-0.002 * \\
(0.061)\end{array}$ & $\begin{array}{l}0.001 \\
(0.611)\end{array}$ & $\begin{array}{l}0.001 \\
(0.241)\end{array}$ & $\begin{array}{l}0.005^{* *} \\
(0.027)\end{array}$ & $\begin{array}{l}0.010 * * * \\
(0.000)\end{array}$ \\
\hline
\end{tabular}

Notes:

This table presents alphas (intercepts) for cross-sectional regressions of portfolio monthly returns on returngeneration factors in the Capital Assets Pricing (CAPM: Sharpe, 1964) and Fama \& French Three-Factor (FF3F: Fama and French, 1992) models. The models are specified as follows;

CAPM: $\left(R_{i t}-R F_{t}\right)=\alpha_{i}+\beta_{m k t}\left(R M_{t}-R F_{t}\right)$

FF3F: $\left(R_{i t}-R F_{t}\right)=\alpha_{i}+\beta_{m k t}\left(R M_{t}-R F_{t}\right)+\gamma_{s m b} S M B_{t}+\tau_{h m l} H M L_{t}+\varepsilon_{i, t}$

The dependent variable is $\left(R_{i t}-R F_{t}\right)$, where $R_{i t}$ is the equal-weighted return of the specified portfolio and $R F_{t}$ is the risk-free rate. The independent variables in the models include $R M-R F$ (excess market return), for the CAPM, and, in addition, $S M B$ (size factor) and HML (book-to-market factor) for the FF3F. UK data for these factors is provided by Gregory et al. (2013). The portfolio holding period is 180 months, from July 1996 to June 2011. The estimate of the constant term provides a test of the null hypothesis that the mean monthly excess return on the calendar-time portfolio is zero. For the same portfolios, monthly buy-and-hold abnormal returns (BHAR) and their bootstrapped skewness-adjusted p-values are also computed as specified in Barber and Lyon (1997) and Lyon et al. (1999). We use alternative benchmark portfolios, including Market benchmark, Size benchmark, book-to-market (BTM) benchmark and a combination of size and book-to-market (Size E BTM) benchmark to compute BHARs. Model (1) shows the returns to corresponding target portfolios when all variables in the conventional model (except dummy variables) are scaled by their 4-digit SIC code industry average. Model (2) shows returns to target portfolios (Model 1) screened for size, leverage and liquidity. The screening involves eliminating all firms with market values in the first and second quintiles, leverage in the fourth and fifth quintiles and liquidity in the first and second quintiles. Model (3) shows the returns to corresponding target portfolios derived by using a multinomial model which predicts targets by method of payment. The target portfolio in this case constitutes the 20 percent of firms with the highest likelihood of receiving a cash bid in each year. Model (4) show returns to Model (3) when the portfolios are further screened for size, leverage and liquidity, as discussed above. Model (5) presents results for the conventional model when a hedge strategy is applied to screened portfolios. This hedge strategy involves screening the target portfolios by size, liquidity and leverage, as above, then short-selling firms with low market values (Q1 and Q2), high leverage (Q4 and Q5) and low liquidity (Q1 and Q2). P-values are shown in parentheses, and ***, ** and * indicate significance at $1 \%$, $5 \%$ and $10 \%$ levels, respectively. 
Figure 1

Proportion of targets and bankrupt firms in predicted target portfolios

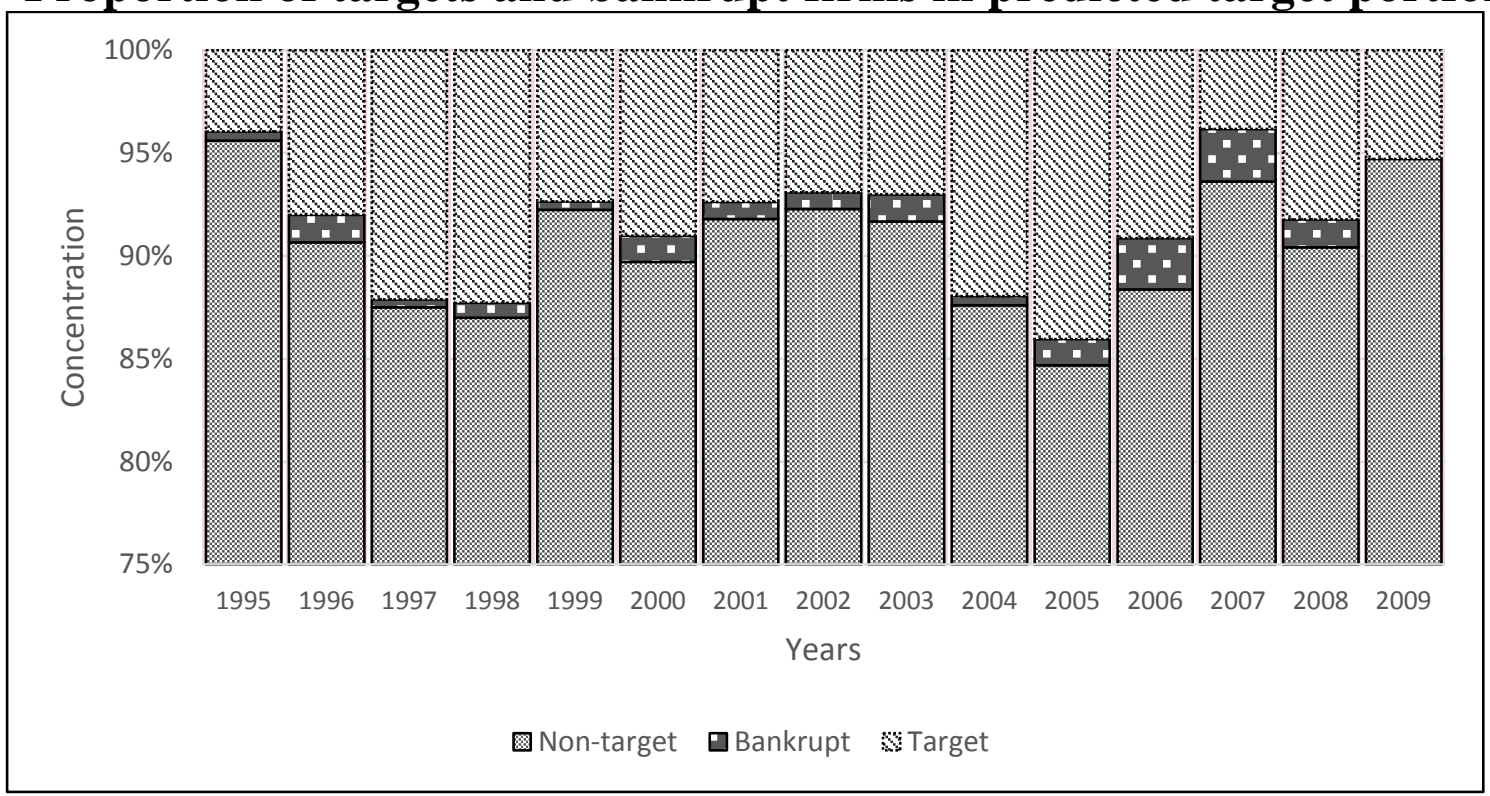

Notes:

This figure summarises the performance of the prediction model in out-of-sample analyses between 1995 and 2009. Concentration refers to the proportion of non-targets, bankrupt and target firms within portfolios of predicted targets. 


\section{Figure 2 \\ Bid announcement dates and stock returns}

Panel A: The distribution of target bid announcement dates
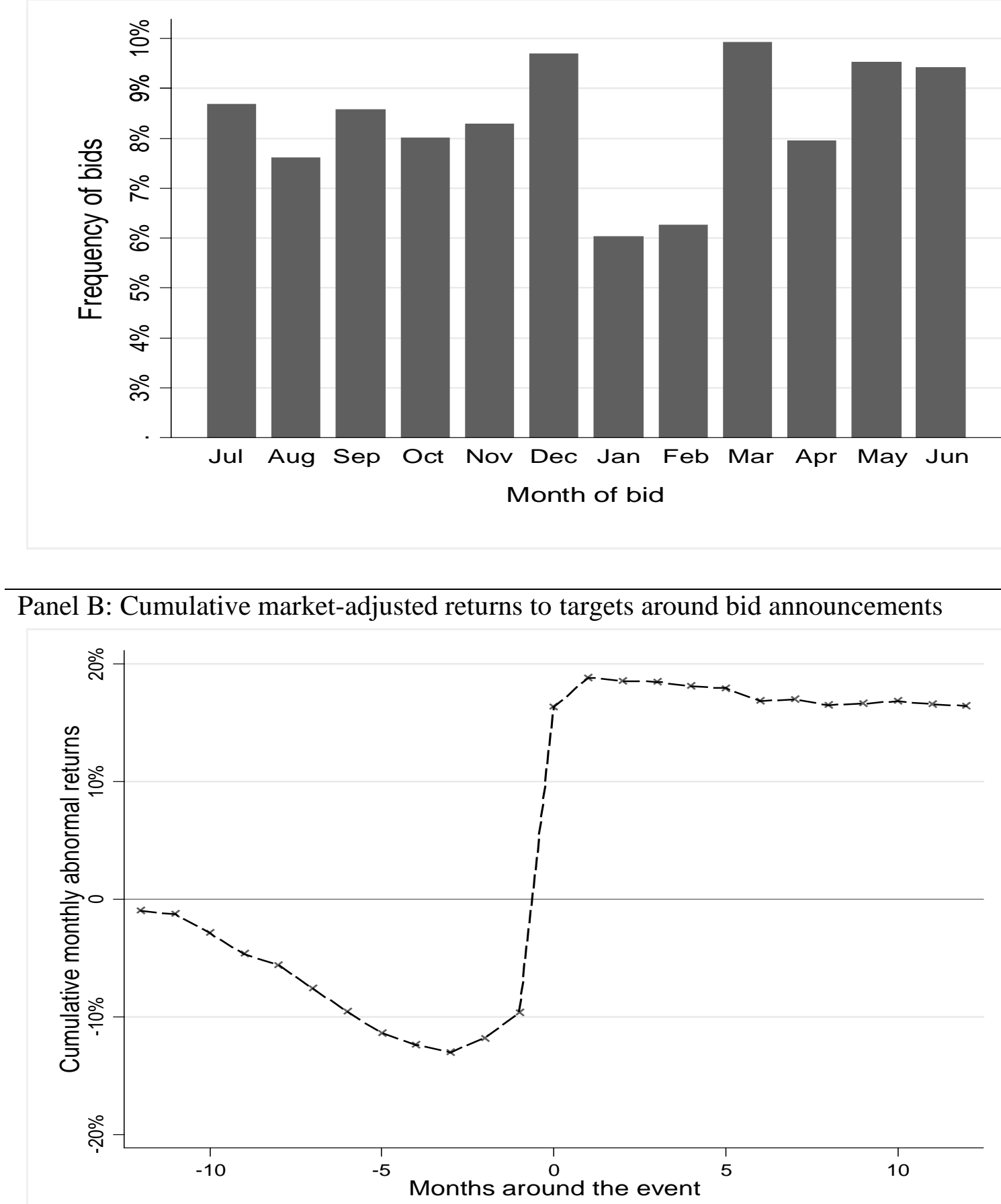

\section{Notes:}

This figure shows the timing and stock market reaction to takeover bids. The analysis is based on all takeover targets in the sample with available data. Panel A shows the distribution of bid announcement months from July to June. Panel B presents cumulative abnormal monthly returns earned during the period starting twelve months prior to (month -12) and ending twelve months after (Month 12) the bid announcement month (month 0). The analysis employs event study methodology to compute the market-adjusted monthly returns to targets around the announcement period. 
Figure 3

Cumulative abnormal returns and takeover likelihood

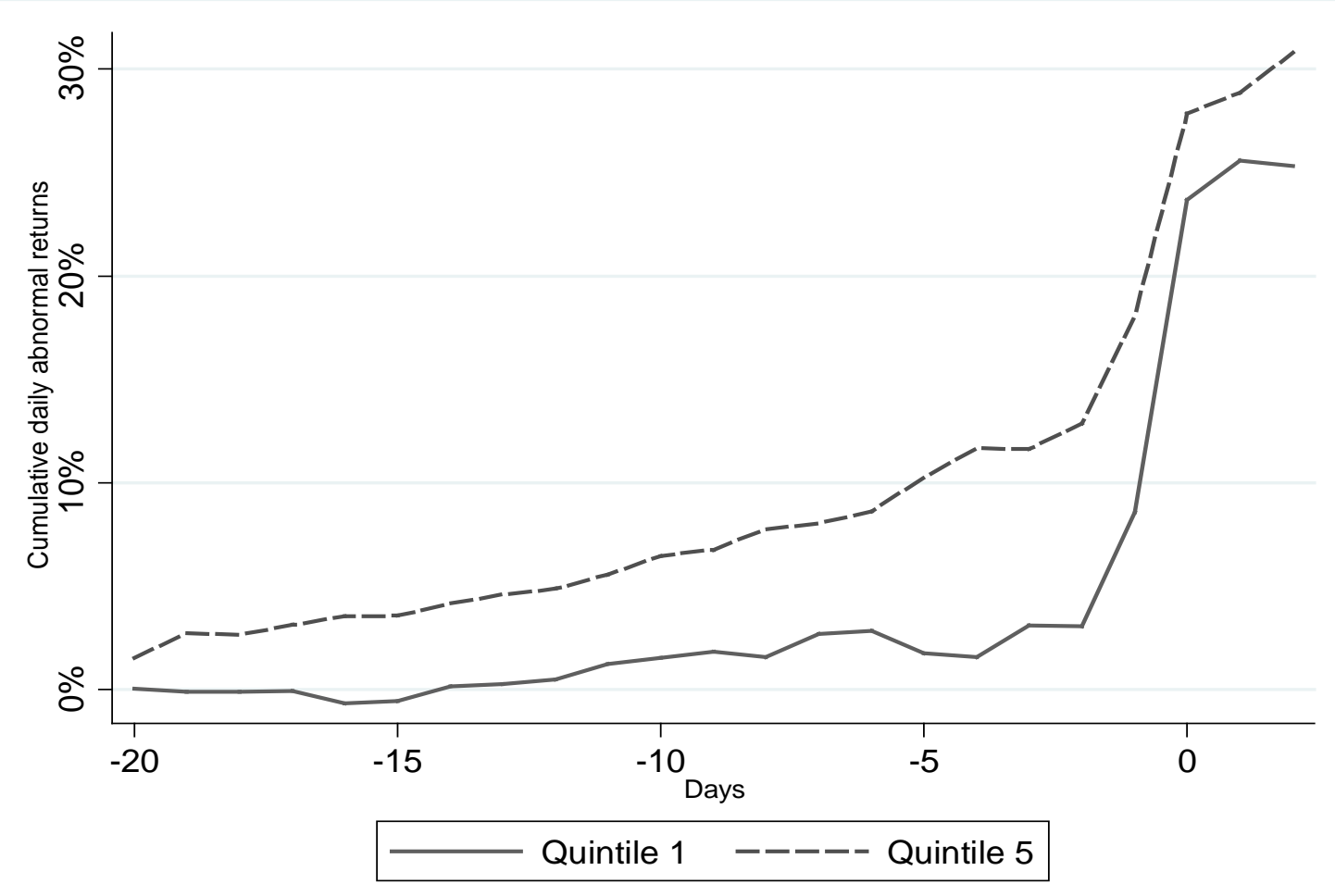

Notes:

This figure shows the cumulative abnormal returns to targets in Quintile 1 (predicted non-targets) and Quintile 5 (predicted targets) around the merger announcement day. Returns are tracked for the month (or 20 trading days) leading up to the bid. Quintile 1 (Quintile 5) represents the 20 percent of firms with the lowest (highest) takeover probability. Daily abnormal returns are computed as the difference between stock returns and market returns during a particular day. These returns are then averaged across the firms in the portfolio to obtain the portfolio's abnormal returns. 
Figure 4

\section{Cumulative abnormal returns and merger rumours}

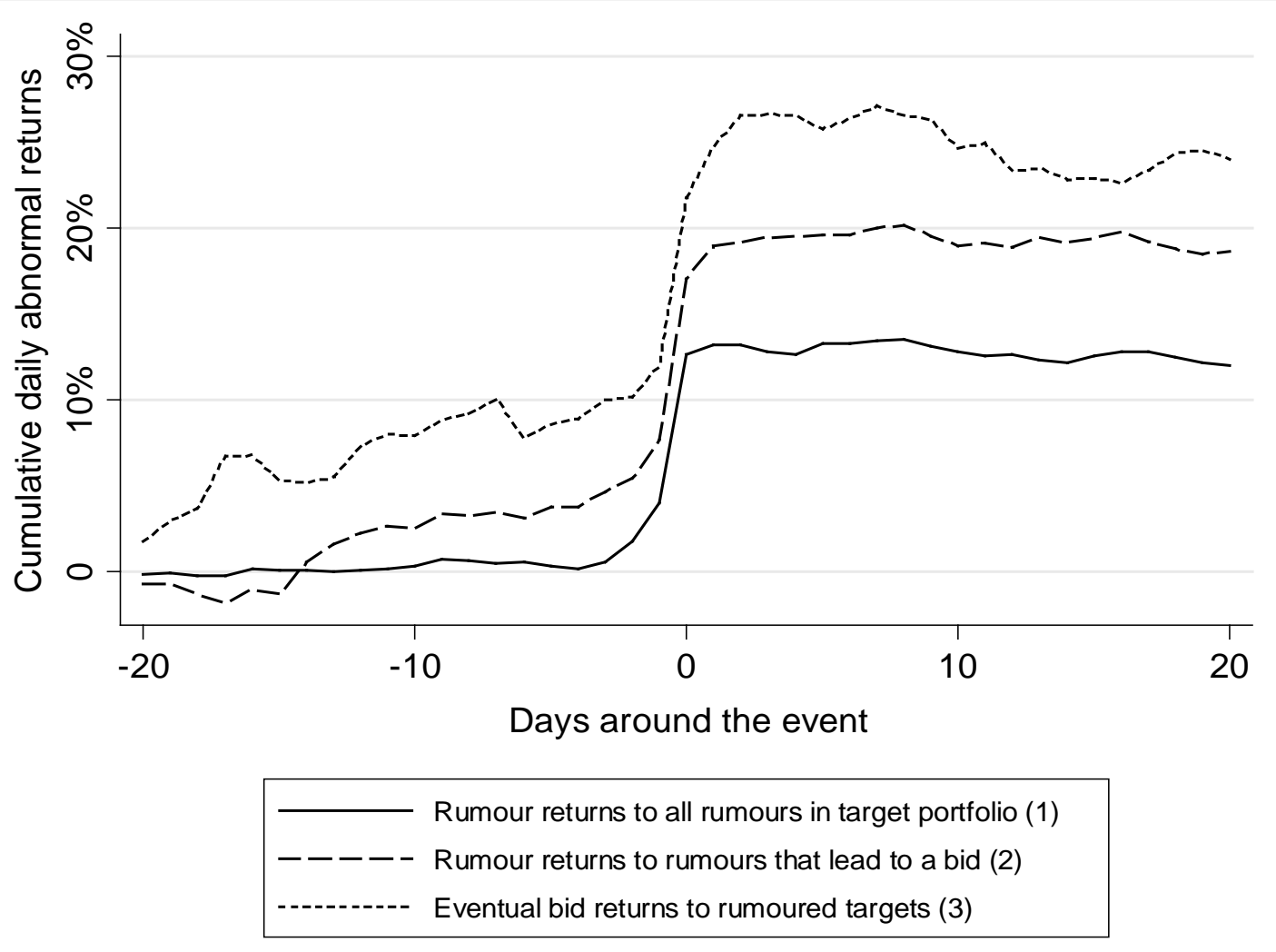

\section{Notes:}

This figure shows the cumulative abnormal returns (1) around rumours, for all rumoured targets in target portfolios; (2) around rumours, for all rumoured targets in the target portfolio that eventually receive a takeover bid; and (3) around merger bids, for all rumoured targets in target portfolios. That is, (2) and (3) plot the rumour returns and eventual bid announcement returns, respectively, for bids which are preceded by merger rumours. The target portfolios represent the 20 percent of firms with the highest takeover probability. Returns are tracked for the month (or 20 trading days) leading up to, and the month after, the rumour emergence or bid announcement day (day 0). Daily abnormal returns are computed as the difference between stock returns and market returns during a particular day. These returns are then averaged across the portfolio to obtain the portfolio's abnormal returns. 